IZA DP No. 8100

The Effects of Occupational Knowledge:

Job Information Centers, Educational Choices, and Labor Market Outcomes

Nils Saniter

Thomas Siedler

April 2014 


\title{
The Effects of Occupational Knowledge: Job Information Centers, Educational Choices, and Labor Market Outcomes
}

\author{
Nils Saniter \\ DIW Berlin \\ and IZA \\ Thomas Siedler \\ University of Hamburg, \\ DIW Berlin, University of Essex and IZA \\ Discussion Paper No. 8100 \\ April 2014 \\ IZA \\ P.O. Box 7240 \\ 53072 Bonn \\ Germany \\ Phone: +49-228-3894-0 \\ Fax: +49-228-3894-180 \\ E-mail: iza@iza.org
}

\begin{abstract}
Any opinions expressed here are those of the author(s) and not those of IZA. Research published in this series may include views on policy, but the institute itself takes no institutional policy positions. The IZA research network is committed to the IZA Guiding Principles of Research Integrity.

The Institute for the Study of Labor (IZA) in Bonn is a local and virtual international research center and a place of communication between science, politics and business. IZA is an independent nonprofit organization supported by Deutsche Post Foundation. The center is associated with the University of Bonn and offers a stimulating research environment through its international network, workshops and conferences, data service, project support, research visits and doctoral program. IZA engages in (i) original and internationally competitive research in all fields of labor economics, (ii) development of policy concepts, and (iii) dissemination of research results and concepts to the interested public.
\end{abstract}

IZA Discussion Papers often represent preliminary work and are circulated to encourage discussion. Citation of such a paper should account for its provisional character. A revised version may be available directly from the author. 


\section{ABSTRACT}

\section{The Effects of Occupational Knowledge: Job Information Centers, Educational Choices, and Labor Market Outcomes*}

This study examines the causal link between individuals' occupational knowledge, educational choices, and labor market outcomes. We proxy occupational knowledge with mandatory visits to job information centers (JICs) in Germany while still attending school. Exogenous variation in the location and timing of $\mathrm{JIC}$ openings allow estimating causal effects in a difference-in-difference setup. Combining linked survey-administrative data with data on JICs permits to detect whether individuals benefited from the comprehensive information service when they were young. The results suggest that individuals, who went to school in administrative districts with a JIC, have higher educational attainments and a smoother transfer to the labor market than students who did not have access to these facilities. However, we find no effects on individuals' earnings in their first job or later in life. Overall, our results confirm the importance of policies that promote occupational knowledge among young adults.

JEL Classification: $\quad$ I2, J24, J31

Keywords: education, uncertainty, job matching, information, job information centers

Corresponding author:

Nils Saniter

DIW Berlin

Mohrenstrasse 58

10117 Berlin

Germany

E-mail: nsaniter@diw.de

\footnotetext{
* We thank Martin Halla, Linda Turner, Deborah Bowen, Birgit Eiber, Martin Detzler, Maria Zintel, Thomas Bauer, Martin Fischer, Rudolf Winter-Ebmer, Daniel Sturm, Eric Lindqvist, Frauke Peter, Katja Görlitz, Andrea Weber, Dan Hamermesh, Philip Oreopoulos, and seminar participants at Maastricht University, Tilburg University, the University of Mannheim, the University of Heidelberg, RWI Essen, the Berliner Network of Labor Market Economists (BENA), the University of Hamburg, DIW Berlin, and the Verein für Socialpolitik for helpful comments and discussions. We also thank Felix Kersting and Thomas Apolke for excellent research assistance and the IAB Nuremberg for data provision.
} 


\section{Introduction}

In most industrialized countries, students have to decide early in life which educational track to follow and what type of job to learn. The educational and occupational choices are often made under uncertainty. Students may be uncertain about their own abilities and tastes, skills needed for particular work, local labor market conditions, future job prospects, or earnings profiles. A key ingredient for making a well-informed labor market decision is the availability of job-related information. While there are different ways to retrieve job-related information privately, in many countries it is publicly provided in the form of occupational education in classrooms or information facilities outside schools.

Among educators and policy makers, there is typically little doubt about the general societal value of publicly providing job-related information (OECD, 2004). However, research to date has been limited in estimating potential benefits of occupational information programs. In particular, there is hardly any evidence on interventions at the national level. We make use of a comprehensive and nationwide reform of occupational education in Germany that involves the establishment of job information centers (JICs) at different times in different regions. Job information centers provide young people with very detailed and comprehensive information on occupations, employment and income prospects, local labor market conditions and educational pathways. Exogenous variation in the location and timing of opening JICs allow causal inference in a difference-in-difference framework. For the present study, linked survey-administrative data were used to analyze various outcomes of students at different points over the life-course, including education and educational mobility, job search and job matching, unemployment experience, as well as earnings.

Theory suggests several reasons why providing comprehensive job information in general-and the availability of JICs in particular-might influence individuals' choices and outcomes. First, providing information about the number and types of occupations and job vacancies available to young people in their region of residence might improve the quality of the match between workers and companies (Miller, 1984). Similarly, providing information about job prospects and

future earnings profiles may lead to efficiency gains if young individuals are more likely to find an occupation that matches their skills and interests (Borghans et al., 2013). Third, job counseling might help students to make choices that are less affected by their parents, prevailing gender roles, individuals' perception of their own identity (Akerlof and Kranton, 2000; Favara, 2012; Borghans et al., 2013). Fourth, recent empirical studies suggest that educational choices are 
influenced by students' expectations about their economic returns to educational fields (Zafar, 2011; Stinebrickner and Stinebrickner, 2011; Papay et al., 2011). Thus, there is reason to believe that job market knowledge acquired through visiting a JIC might alter students' expectations and, as a result, impact on their educational choices and long-term labor market outcomes.

Our empirical estimates suggest that the availability of a job information center causes a large and significant increase in the likelihood of experiencing upward educational mobility, and improves chances of acquiring the highest general school degree. For instance, the likelihood of experiencing upward educational mobility increases by around 8-12 percentage points. Individuals who went to school in an administrative district with a JIC are also less likely to become unemployed or to involuntarily lose their job at the beginning of their labor market career. Further, the estimates appear to indicate that visiting a JIC improves job matching. However, we find no positive impact on individuals' earnings in their first job or later in life. These findings are robust to the inclusion of various explanatory variables, for various sub-samples and different time trends. Our results are consistent with previous studies reporting that information programs are effective at improving individuals' educational choices. In particular, our findings are in line with a recent study by Rodríguez-Planas (2012) who reports positive effects of a randomized mentoring program in the United States on educational choices, but no effects on labor market outcomes. Exploiting variation across regions and over time enables us to measure general equilibrium effects. As such, we complement the local estimates from randomized experiments among upper school students from selected colleges or universities (Booij et al., 2012; Wiswall and Zafar, 2011; Oreopoulos and Dunn, 2013).

In the difference-in-difference research design, a key assumption for identification is that there are no contemporaneous shocks or changes on the district level that are correlated with the establishment of JICs and the various outcome measures. We present detailed evidence to verify this assumption. First, we present graphical evidence supporting the common trend assumption for various educational and labor market variables. Second, we estimate survival analysis models showing that the timing of JIC openings is uncorrelated with contemporaneous or pre-determined variables on the district level. The estimates show that the timing of JICs opening is not statistically significantly correlated with initial educational and labor market characteristics. For example, JICs were not more likely to open sooner in districts with a high youth unemployment rate, or in regions with a high proportion of educated people. Further, we find no empirical evidence that pre-existing trends in education or local labor markets are correlated with the timing of JICs opening. 
The remainder of this paper is structured as follows: Section II summarizes the relevant literature. Section III provides details on the institutional background of job information centers, their role in occupational education in schools, how they work, and when they opened (across years and districts). Section IV describes the data and presents summary statistics. Section $\mathrm{V}$ provides details on the estimation method and identifying assumptions, which are further discussed on the basis of graphical evidence and survival estimates in Section VII. Section VI presents the results, Section VIII presents robustness checks, and Section IX concludes.

\section{Related Literature}

This paper is closely related to the literature on the effects of counseling and mentoring on individuals' educational choices and labor market outcomes (Borghans et al., 2013; RodríguezPlanas, 2012). Rodríguez-Planas (2012) examines the effects of a randomized program offering mentoring by case workers, educational services, and financial awards over a five-year period to low-performing high school students in the United States. The study reports positive effects on high school completion and post-secondary education, but little evidence on labor market outcomes five years after the end of the program (e.g., hours worked, having a full-time job, and pay). Borghans et al. (2013) study the impact of counseling at high school on the quality of tertiary educational choices in the Netherlands. The authors use variation in the intensity of counseling practices between high schools as exogenous variation for students' decisions whether or not to seek career counseling. The study finds a positive influence of counseling on students' own evaluation of their educational choices 18 months after graduating from tertiary education. The effects of visiting a study counselor are particularly beneficial for graduates with a migrant background and for those whose parents have lower levels of education. ${ }^{1}$

A second related literature studies the importance of information and subjective expectations. Several papers report that individuals modify their beliefs and behavior in response to new information (Dominitz, 1998; Hastings and Weinstein, 2008; Jensen, 2010; Martínez and Dinkelman, 2013; Nguyen, 2008; Oreopoulos and Dunn, 2013; Stinebrickner and Stinebrickner, 2011; Wiswall and Zafar, 2011; Zafar, 2011), whereas others find no evidence that providing information changes people's behavior (Booij et al., 2012). Many studies in this strand of literature exploit exogenous variation through randomized trials to study the impact of interventions on

\footnotetext{
${ }^{1}$ Note that we do not review the counseling and monitoring literature for unemployed people here. Recent studies that examine the effects of job-search counseling for unemployed individuals are, for example, Hainmüller et al. (2009) and Vikström et al. (2011).
} 
individuals' educational choices and revealed preferences. ${ }^{2}$ The studies by Zafar (2011), Stinebrickner and Stinebrickner (2011), Oreopoulos and Dunn (2013) and Wiswall and Zafar (2011) are particularly relevant to our analysis. Zafar (2011) examines how students form expectations about major-specific outcomes and how they resolve uncertainties in their educational decisions. Using longitudinal survey data on a sample of university undergraduates, the author finds that learning plays an important role for students' educational choices and that students' updating process is consistent with a Bayesian learning model. Similarly, Stinebrickner and Stinebrickner (2011) study how low-income college students update their beliefs about choice of college major. The authors find that students are quite open to majoring in math or science at the start of college, but that many move away from these majors after learning about their own skills and realizing that their grades will be lower than originally expected if they focus on these subjects.

Oreopoulos and Dunn (2013) study the effect of information provision on educational attainments. Students from high schools in low-income neighborhoods in Toronto are being provided accurate information by means of a promotional video about the costs and benefits of attaining higher education and loan eligibility. The authors report that students who have been exposed to the educational information report higher expectations of their own returns to post-graduate education, express a higher likelihood that they are eligible for a grant, and are more likely to say that they aim to completing a college degree three weeks after the intervention. The authors also report evidence that the intervention changes students' behavior: those who are shown the video are more likely to download additional information about higher education and specific colleges and universities from the Internet. Wiswall and Zafar (2011) examine whether providing new information alters students' beliefs and their choice of college major. Their longitudinal analysis shows that individuals make substantial errors in population beliefs and revise their self-beliefs in response to new information. Among other things, the authors conclude: "This suggests that information campaigns focused on providing accurate information on returns to schooling could have a large impact on beliefs and choices of students." (Wiswall and Zafar, 2011: 35).

The aim of the present paper is to contribute to this literature by studying the effects of introducing a comprehensive and nationwide occupational information program on individuals' educational choices and labor market outcomes by opening JICs in Germany. We are able to study short-term (e.g., educational attainment of secondary schooling, educational upward mo-

\footnotetext{
${ }^{2}$ See, for example, Hastings and Weinstein (2008); Nguyen (2008); Jensen (2010); Martínez and Dinkelman (2013); Booij et al. (2012); Wiswall and Zafar (2011); Oreopoulos and Dunn (2013).
} 
bility), medium-term (e.g., labor market outcomes in the first five years after entering the labor market) and long-term effects (e.g., earnings and geographic mobility 15 to 20 years after entering the labor market). Further, this study uses quasi-experimental evidence on young people from different types of school and with heterogeneous educational backgrounds. Unlike authors of other studies, we are able to estimate effects for an entire country. Thus, we complement experimental studies based on university student populations (Wiswall and Zafar, 2011; Booij et al., 2012) or students from high schools in one city (Oreopoulos and Dunn, 2013). Another important contribution is that we examine the effects of information provision that is very detailed and comprehensive, since job information centers provide information media on hundreds of different occupations, vocational training and apprenticeships, higher education, job descriptions, earnings and employment prospects, and information about the local labor market.

\section{Job Information Centers: Description, Survey Evidence, and Development over Time}

This section provides an overview of the functioning and aims of job information centers in Germany, and summarizes key findings from various surveys conducted among visitors. It also discusses the development of information centers over time and across regions.

\section{A. Description, Aims, and Institutional Background}

A job information center (Berufsinformationszentrum) is a public establishment that provides detailed and comprehensive information on occupations, vocational training and apprenticeships, higher education, job tasks, earning prospects, and local labor market conditions. The goal of job information centers is to provide specific, up-to-date, detailed occupational information and, if required, counseling to facilitate individuals' labor market-related choices. The centers are designed to combine visitors' autonomous retrieval of information with assistance from professional job counselors (Jenschke, 1979c; Weitzel, 1988). Entry to JICs and counseling interviews are free of charge.

There are several ways visitors can access the resources to acquire the information they need. First, visitors can use various media, such as information folders, computers, career videos, books, slide shows and documentaries. ${ }^{3}$ In a representative survey of around 10,000 visitors to job information centers in 1997, 90 percent report consulting information folders, 72 percent used computer programs, 62 percent books and 29 percent slide shows (Kretschmer

\footnotetext{
${ }^{3}$ On average, visitors consult 3.2 different forms of media (Kretschmer and Perrey, 1998).
} 
and Perrey, 1998). Hence, the most important type of media are folders. ${ }^{4}$ Each folder contains detailed descriptions of the work available, responsibilities involved, educational requirements, availability of training positions in the local labor market, and income and employment prospects for one particular occupation. For example, Figure A-1 in the Appendix displays a copy of the contents page of the information folder for the occupation of a salesperson in the food trade (Verkäufer im Nahrungsmittelhandwerk), copied from Weitzel (1987). The JICs supply a folder like this for almost every occupation. ${ }^{5}$ Apart from the provision of stationary media, JICs also serve as venues for job choice-related events, such as seminars and talks by occupational counselors, educators, or trade organizations, training, and job fairs (Jenschke, 1979b; Lohmann, 1988; Weitzel, 1988). Visitors can also take away reading and information material. Massute (1984) points out that over 50 percent of all visitors report collecting leaflets with descriptions of occupations to continue reading at home.

The primary target group of JICs are young people, mostly students in secondary school, who will soon enter the labor market (Massute, 1984; Weitzel, 1988). Typically, teachers take their classes to visit a JIC. But older adults, who would like to seek new professional opportunities or return to the labor market after an absence, are also welcome to retrieve the job market-related information at the centers. Around 70 percent of all visitors are students who visit a JIC with a school class and their (head) teacher (Kretschmer and Perrey, 1998). They typically spend a full school day there. At the start of the visit, a job counselor explains how the job information centers works, gives an overview of the media available, and invites students to come back to the JIC at any time in the future. After the introductory presentation, students are usually left on their own to autonomously retrieve any information they wish (Beinke, 1988). In most cases, students will already know the job counselor, since she or he normally visits the class in school prior to the trip to the job information center. Hence, education about occupations begins with a job counselor's visit to a school and through information provided by teachers. In fact, 80 percent of all visitors to JICs say that they first heard about the JIC in school (Massute, 1984).

The German Federal Employment Agency (Bundesagentur für Arbeit, BA) is responsible for the conceptual development, implementation, and running of the job information centers as publicly funded institutions. JICs are physically separated from other BA facilities, but

\footnotetext{
${ }^{4}$ Schweikert and Meissner (1984), Hermanns (1989) and Perrey (1995) also report that around nine out of ten young people read information in folders during their visit to a job information center.

${ }^{5}$ For example, Jenschke (1979b) points out that the very first job information center in Berlin had 260 information folders, covering more than 90 percent of all occupations, apprenticeships, and study degree programs on offer in Berlin at that time.
} 
often located in the same building or near BA job centers. This study makes use of the fact that the BA agreed with the Standing Conference of the Ministers of Education and Cultural Affairs (Kultusministerkonferenz) to make a school trip to a JIC an integral part of occupational education at school (Rahmenvereinbarung, 2004). Regional agreements with the regional school administrations stipulate that eligible students have to visit a JIC no later than two years before they leave secondary education. For instance, the agreement with the state of Bremen reads: "The minimum occupational counseling for each school grade is one session of occupational orientation at school and one at a job information center" (Vereinbarung, 2011, 4, translated from German). We chose the administrative unit of German districts (Kreise) as the geographical area to distinguish between treated and untreated areas. Using the level of Germany's 413 districts ${ }^{6}$ for the analysis is superior to using the next higher level of the 16 federal states, since districts are of smaller size and better reflect local labor market areas. In contrast, using a lower level of 12,263 municipalities would lead to inaccuracies as the catchment area of JICs stretches beyond municipal boundaries. Finally, from Jenschke (1979a) we know that, from the outset, schools and JICs were urged to cooperate in order to reach 100 percent coverage in hosting all students from the locality where the JIC was established.

\section{B. Existing Survey Evidence}

Over the years, several surveys have been conducted among visitors to job information centers. The most relevant ones are the representative surveys of all existing job information centers commissioned by the Federal Employment Agency. These surveys were conducted in the years 1988, 1991, 1992, 1994, and 1997 (Hermanns, 1989, 1992; Perrey, 1995; Kretschmer and Perrey, 1998). In addition, Massute (1984) interviewed 369 visitors to the job information center in the city of Hanover in August 1983, and Schweikert and Meissner (1984) conducted a survey of 3,032 respondents who visited the JIC in Berlin in 1980. The surveys include questions on age, gender, nationality, employment status, and various questions about the visit to the JIC (e.g., level of satisfaction, knowledge gained, usefulness of the resources, length of stay, number of visits). The key findings of these surveys can be summarized as follows:

(a) The majority of visitors are students. Kretschmer and Perrey (1998) report that 69 percent of all visitors to JICs are students, with 57 percent of all visitors being aged 16 or younger, and 13 percent aged 17 to 18. Similarly, Massute (1984) reports that 71 percent

\footnotetext{
${ }^{6}$ The number of geographical units reflects the status as of December 31, 2008.
} 
of all visitors to JICs in the city of Hanover are 12 to 18 years old.

(b) Most students are attending low- or intermediate-track secondary schools. The majority of students are attending low (Hauptschule) or intermediate-track secondary schools (Realschule or Gesamtschule) when they visit a job information center. For example, Kretschmer and Perrey (1998) report that 16 percent of the students attend low-track and 48 percent intermediate-track schools. Only around 26 percent attend upper-track schools (Gymnasium). ${ }^{7}$

(c) Positive spillover effects. The study by Massute (1984) points to important positive spillover effects. He writes (translated into English): "But inferences about a possible multiplier effect can also be drawn. Visits with friends make up around 30 percent of all visits to job information centers. That is, in many cases, a visit to a JIC with a school class is followed by one or more further visits with friends, for whom the information facility may be new" (Massute, 1984, 197)..$^{8}$

(d) Multiple visits and length of stay. Schweikert and Meissner (1984) interviewed 1,021 students who visited the job information center in Berlin in 1980 together with their teacher and classmates during school hours, and 2,011 young people who visited the JIC in Berlin on their own initiative. Among those who came on their own (or together with a friend), 75 percent said that they had visited a job information center previously. On average, individuals visit the JIC twice. Overall, the authors report that 24 percent stated that they were visiting the JIC for the first, 36 percent for the second, and 40 percent responded that they were visiting a JIC for the third or more times (Schweikert and Meissner, 1984). On average, people spend between one and two hours at the information facility, with 29 percent of all visitors staying for two hours or more (Kretschmer and Perrey, 1998).

(e) Positive feedback from visitors. The majority of visitors give positive feedback about their visit to a job information center. Schweikert and Meissner (1984) interviewed visitors about their level of satisfaction with the visit in general, and about their level of satisfaction with the resources and media used in particular. Among respondents who attended a talk about a particular occupation, 75 percent claimed that they learned new facts, and

\footnotetext{
${ }^{7}$ In line with these findings, Massute (1984) reports that around 80 percent of all visitors are students attending low- or intermediate-track schools when visiting a JIC.

${ }^{8}$ Similarly, Schweikert and Meissner (1984) report that 26 percent of all visitors who visited the JIC on their own learned about the job information center through friends.
} 
60 percent described the talk as "easy to understand." In addition, 90 percent of all respondents gave a positive response to the question "Can you recommend the talk at the job information center?" (Schweikert and Meissner, 1984). ${ }^{9}$ Similarly, 78 percent said they were "very satisfied" or "satisfied" with the visit (Kretschmer and Perrey, 1998). The authors also report that 97 percent of visitors were able to find the information they wanted. Table 1 gives an overview of the gains in knowledge among students who visited a JIC together with their school class. The table shows that-after visiting a job information center-over 60 percent of all students said that they knew more about many aspects of occupations they were interested in: the school degree generally required, how an apprenticeship is structured, the availability of trainee positions, and the manual and intellectual skills needed. However, the responses also indicate that only one in three visitors claimed to know more about earning prospects after their visit to a JIC.

(f) Visitors come from nearby. There is also evidence that most visitors to job information centers come from the district or city where the JIC is located. For instance, Massute (1984) reports that almost all visitors to the job information center in the city of Hanover actually come from Hanover (92 percent).

Beside these stylized facts, many educators and occupational counselors argue that the establishment of job information centers considerably improved occupational education in Germany (Jenschke, 1979c) and cooperation between local schools and career counselors, and that students are very eager to acquire new information during their visits to job information centers. Lohmann (1988) writes: "Previous experiences with the existing occupational information centers show that the Federal Employment Agency has hit the mark with this service. The facility has been received extremely well by users of all ages and is highly valued by the professionals in career counseling, employment services, and job placement as an aid to their work" (Lohmann, 1988, 125-126). Jenschke (1979b) quotes from a report by a school class after visiting a JIC: "The class was interested throughout the entire time and would like to take advantage of the opportunity to gather further information there, either alone or with their parents, or to visit events there" (Jenschke, 1979b, 139).

\footnotetext{
${ }^{9}$ The positive evaluation of the media is very stable over time. Respondents to the representative surveys in the years 1988, 1991, 1994, and 1997 all evaluated the information folder as "good", on average (Kretschmer and Perrey, 1998).
} 


\section{Development of Job Information Centers over Time and across Regions}

The Federal Employment Agency first contemplated the idea of permanently providing information materials about occupations and career paths outside existing job centers in 1970 . In November 1976, the first JIC opened in Berlin. As it was widely considered to be a success (Siebert, 1979), in October 1979, the council of the BA decided to establish similar JICs throughout Germany. It was agreed that the JICs would first open in cities with over 500,000 inhabitants (including catchment area) and that there should be a regionally balanced distribution throughout Germany. ${ }^{10}$ It was also decided that all JICs should have the same structure and equipment (Nieder, 1980). Beside these criteria, the timing of the establishment of job information centers seems to be as good as random. On June, 5, 2013, the authors of this paper had a meeting with the team leaders of the department "Berufsinformationszentrum (BIZ)" at the headquarters of the Federal Employment Agency in Nuremberg. The experts confirmed that the timing of the opening of the JICs was not influenced by external factors (e.g., local labor market conditions, local educational requirements etc.) and happened in a rather unsystematic, random fashion. It is also important to point out that the decision when to open a JIC in a particular area was not made by local politicians. Hence, it is unlikely that districts more in favor of investing in education, or more supportive of active labor market policies, are also more likely to open a JIC earlier than others. In fact, a key identification assumption of our difference-in-difference research design is the exogeneity of the timing of job information centers being opened. This issue will be dealt with in more detail in Section VII below.

Figure 1 shows the evolution of job information center openings over time. Panel (a) displays the development of the number of JICs, and panel (b) plots the percentage of districts with a JIC. The figure shows that the establishment of JICs varies considerably over time. In particular, there was a steady and large increase in the number of JICs in West Germany between 1976 and 1990. After German reunification in 1990, JICs also opened in former East Germany. Overall, 181 job information centers were opened in 175 out of 413 districts. ${ }^{11}$

Figure 2 shows the regional distribution of job information centers at the district level over time. Shaded areas indicate districts with a JIC, and white areas districts without a JIC. Panel (a), for example, shows that in 1980, there are 13 districts with a job information center. By the year 2000, job information centers had been opened in 42 percent of all districts. It appears

\footnotetext{
${ }^{10}$ Hirsch (1974) writes with respect to the first JICs in large cities that at least one job information center should open in each federal state.

${ }^{11}$ Note that Figure 1 only displays the opening of 175 job information centers since we have no valid information on the opening date for four JICs and two JICs in Berlin were later closed.
} 
that the regional distribution is indeed balanced, although the West German Ruhr area seems to show a higher density of treated districts than elsewhere. ${ }^{12}$ It can also be observed that small-area, urban districts are more frequently treated than sparsely populated, rural districts.

\section{Data, Variables and Descriptive Statistics}

\section{A. Datasets}

We use information from four different datasets. The primary data source is the ALWA study (Arbeiten und Lernen im Wandel, Working and Learning in a Changing World) provided by the Research Data Center of the German Federal Employment Agency (IAB) (Antoni et al., 2011). The ALWA dataset contains detailed longitudinal information on 10,404 randomly selected individuals who were interviewed in 2007 and 2008. Monthly spell data allow us to trace out the respondents' trajectories in the fields of education, training, employment, and unemployment, as well as their residential history. The survey also contains information on parental background and labor market outcomes elicited at the time of the interview. Most importantly, ALWA includes information on the administrative district of residence at any point in the respondents' lives. We make use of this information in order to assign each individual to a district either with or without a JIC while they are in secondary school. ${ }^{13}$

We make use of a version of ALWA that is complemented by administrative data from the social security records, forming the ALWA-ADIAB dataset (Antoni and Seth, 2011), as shown in Figure A-2 in the Appendix. These administrative records comprise daily spell data ranging back to 1975 for western Germany, and 1992 for eastern Germany. Further variables in the administrative data contain information on employment, gross daily pay, type of job, occupational and industrial classifications, and some employer characteristics. The survey and administrative data are linked through a matching algorithm and this is conditional on the respondent's consent. Out of all ALWA respondents, 8,166 individuals (78 percent) are successfully linked with the administrative data.

The administrative data ADIAB is a subsample of a much larger dataset called the Sample of Integrated Labor Market Biographies (SIAB) (Dorner et al., 2010) that is unrestricted to successful matching with ALWA. The SIAB, in turn, is a two percent random sample drawn

\footnotetext{
${ }^{12}$ In the sensitivity analysis in section VIII, we examine the robustness of the estimates when we exclude the Ruhr area from the sample.

${ }^{13}$ In the dataset available to researchers, the code of the district of residence is anonymized. Fortunately, the IAB agreed to run our Stata program on the original dataset, thereby generating our treatment variable. We are very grateful for this assistance.
} 
from the Integrated Employment Biographies (IEB). The IEB consist of all individuals known to the German social insurance agency, including those who are receiving unemployment benefit or are searching for a job (excluding the self-employed and civil servants). The observations go back to 1975 (for West/western Germany) and 1992 (for eastern Germany) and are reported on the district level. The SIAB comprises approximately 40.5 million daily spell entries for 1.66 million individuals. We use this remarkably large dataset to assess the common trend assumptions and to generate district-level variables for the survival analysis regressions in Section VII. We match the ALWA and ALWA-ADIAB data with self-collected data on the location and opening dates of the job information centers. Moreover, we merge in data on the the population density (on the district level) from the German Federal Statistical Office. ${ }^{14}$

\section{B. Outcome Measures and Treatment Variable}

This section describes the definition of the various outcome measures and the treatment variable. An overview and description of the variables can be found in Table A-1 in the Appendix. We categorize the outcome variables under the following four topics: education and educational mobility, labor market attachment, job search and job matching, and wages and income.

Education and educational mobility. In Germany, there are three main types of secondary schooling which may be described approximately as: low-track school (Hauptschule), intermediatetrack school (Realschule) and grammar school (Gymnasium). Hauptschule is the lowest level of secondary schooling and ends after a minimum of nine years of schooling, at the age of 15 or 16, with the qualification Hauptschulabschluss. Students who successfully finish the intermediate school track after ten years of formal schooling receive the school certificate Mittlere Reife. Students from the low- and intermediate-track schools normally proceed to vocational training and begin an apprenticeship or move on to the next highest school track. The grammar school is the most prestigious and academic school track. It ends after 12 or 13 years of schooling with the Abitur certificate, which is the highest secondary-school qualification and enables individuals to enter technical colleges and universities. ${ }^{15}$

The educational outcome measures are defined as follows. The dichotomous variable lowtrack school degree means having completed the general school track. Intermediate-track school degree is also a dichotomous outcome variable equal to one if the individual completed ten years of schooling and received Mittlere Reife, and zero otherwise. The dichotomous variable

\footnotetext{
${ }^{14}$ We use the population size of the year 1995 as earlier records are not available at the district level.

${ }^{15}$ For a more detailed description of the German school system, see, for example, Winkelmann (1996), Dustmann (2004) and Francesconi et al. (2010).
} 
upper-track school degree equals one if the individual received an Abitur, and zero otherwise. The three outcome measures low-, intermediate- and upper-track school degree are mutually exclusive and always measure the highest general school degree attained. Our fourth outcome, upward mobility, is equal to one if an individual experienced upward educational mobility, and zero otherwise. ${ }^{16}$ Finally, the educational outcome university degree is a dichotomous variable equal to one if an individual has a technical college or university degree, and zero otherwise.

Labor market attachment. To capture labor market attachment at the beginning of individuals' careers, we measure whether they experience part-time employment, full-time employment or unemployment during the first five years after completing their education. For example, the variable part-time employment equals one if an individual works part-time for at least one month during the first five years after finishing the last episode of formal education, be it general schooling, vocational training, or higher education. Similarly, the dichotomous outcome variable full-time employment (unemployment) is equal to one if an individual works full-time (experienced unemployment) for at least one month during the first five years after completing formal education, and zero otherwise. We not only measure employment incidences, but also the time spent by individuals' in part-time employment, full-time employment and unemployment, measured in months. For instance, the variable unemployment duration measures the number of months individuals are unemployed in the first five years after entering the labor market. Note that the duration variables are restricted to values between 0 and 60 .

Job search and job matching. The variable search duration measures the number of months individuals search for employment after completing vocational training or higher education. It is coded zero when the transition into a job immediately follows education, or when the education spell is still ongoing when entering regular employment. As proxy variables for job match quality, three different outcomes were generated. First, it was measured whether, at the time of the interview in 2007 or 2008, individuals still lived in the same district (or federal state) as when they were young, i.e., at the age of potential visiting a JIC. The basic idea of these two geographic outcome measures is that if the availability of and visits to JICs improves matching between employers and employees in the local labor market, the need to move away is lower than without the proximity of a job information center. Hence, if a higher proportion of individuals staying in the local area is observed when there was a local job information center during their

\footnotetext{
${ }^{16}$ For example, if an individual attended a low-track school (Hauptschule) in the year of potentially visiting a JIC and later completed his or her general schooling with a Mittlere Reife or an Abitur, we define this person as experiencing upward educational mobility. Another possibility of upward mobility is attending an intermediatetrack school initially and later leaving school with the Abitur certificate.
} 
youth, this is interpreted as indirect evidence of a better job matching. Our final proxy variable for job match quality measures the share of involuntary job changes in the first five years after completing formal education. We make use of an item in the ALWA questionnaire that asks for the reason for the end of an employment spell. Respondents can report whether employment was terminated by themselves, by the employer, or whether the contract ended officially according to prior agreement. For the first five years of individuals' labor market careers, we count the number of times they report losing a job involuntarily and relate this to the total number of times each individual changes employers. Thus, the outcome variable share involuntary job change takes on values between 0 and 1 .

Wages and income. We use the administrative data from ALWA-ADIAB to measure daily pay in an individual's first job and at the age of $35 .{ }^{17}$ The pay at the age of 35 is simply the average daily salary in the year an individual turns 35 years old. Hence, individuals whom we cannot observe at the age of 35 are excluded from the regression. ${ }^{18}$ Finally, survey respondents were interviewed about their pay in their last job and their net income at the time of the survey in $2007 / 2008$. The income and wage measures are in logarithms and are trimmed at the 1st and 99th quantiles.

Treatment effect-Job information center. Selection into treatment is based on the availability of a JIC in the administrative district where the individual went to school. Since no variable in the survey directly informs about the availability of a JIC during an individual's youth, we use monthly spell information on school track, school degree, the district of residence, and the location and opening dates of job information centers. We know that schools send their students to JICs in different grades according to the school track attended, normally two to three years before they leave school (Schweikert and Meissner, 1984, and Section III above). Hence, students from the same cohort are typically treated at different ages if they attend different school tracks. Relative to the year of graduation from school, we calculate a potential treatment year, $t{ }^{19}$ Table A-2 in the Appendix gives an overview of how we define $t$ for different combinations of school tracks and school degrees. Typically, the school type defines the type

\footnotetext{
${ }^{17}$ The wage of the first job is taken from the first observable monetary compensation from regular employment observed in the administrative part of the data. However, the first spell in the ADIAB may be subject to left censoring and may follow earlier spells of unreported self-employment or civil service. To make sure it really is the wage of the first job, we compare the spell's year to the year, for which the individuals report their first regular employment in the questionnaire. We only consider observations, for which the difference between these two dates is not more than \pm 1 year.

${ }^{18}$ Individuals with fewer than 180 employment days in the respective year are considered to have instable jobs and are also excluded.

${ }^{19}$ We call it potential because we yet have to determine whether a JIC was actually available in the district of residence or not.
} 
of qualification (e.g., intermediate-track school leads to Mittlere Reife and a grammar school leads to Abitur). Table A-2 shows that, for instance, students who attend an intermediate-track school and successfully receive an intermediate-track school degree are defined as being treated two years before leaving school. In real life, the accordance between school track and school degree often holds, but not always. For example, a student may drop out of grammar school after 11 years with a Mittere Reife, which is a lower qualification than an Abitur. Different reasoning applies to this constellation. The early drop-out is treated closer to graduation because the teachers still take their students to the JICs two or three years prior to typical graduation. The early drop-out from a grammar school leaves two years earlier than his classmates. He or she is therefore treated $3-2=1$ year before the end of his or her spell.

Using potential treatment years relative to the year of graduation has consequences for the educational composition of the treatment and control group. To illustrate this, consider a district which hosts a job information center. Assume that this district has only two residents, both born in the same year. One attends the lowest school track, and the other the highest. Assume further that a JIC openes when both are aged 16. Now, using the treatment rule relative to the time of graduation, only the higher educated individual is treated, while the lower educated is not (the typical graduation age in the lower track is 15 or 16). Hence, treatment status depends on the age and school track attended. Therefore, in the regressions below, we always control for the school type attended when individuals are potentially treated and dummy variables for the year of birth.

\section{Sample Selection and Descriptive Statistics}

The final estimation sample consists of all individuals in the ALWA dataset for whom the treatment variable and the outcome measures can be derived and who were born between 1960 and 1982. The 1960 birth cohort is the earliest that might have been treated by visiting the first JIC in the city of Berlin after it opened in 1976, given the typical graduation age in the lowest school track. Individuals born after 1982 would be too young for meaningful outcome measures.

Three different samples are distinguished. The Full sample includes all individuals for whom we have valid information for the key variables. The Reduced sample I comprises all individuals who attended either the low- or intermediate-track schools at the time of potentially visiting a job information center. These two samples are distinguished because educators and occupational counselors argue that the information media at JICs are more beneficial and comprehensive for students in low- and intermediate-track schools than for those in the upper-track 
schools (Massute, 1984). Moreover, the majority of students visiting a JIC attend a low- or intermedium-track school (Perrey, 1995; Kretschmer and Perrey, 1998). For example, Schweikert and Meissner (1984) report that only nine percent of all students who attended talks about particular occupations were at grammar school. Hence, the magnitude of the treatment effects is likely to be stronger among individuals from the low- or intermediate-track schools. Finally, the Reduced sample II comprises only individuals who attended either low- or intermediate-track schools and, at the time of potential treatment, also lived in one of the 175 districts where a JIC opened between 1976 and 2010. This implies that all individuals who grow up in a district where no JIC ever opened are excluded from the Reduced sample II. It therefore captures the within dimension of the variation. The main reason for including this third sample is that some individuals who were defined as part of the comparison group in the Full sample and Reduced Sample I (i.e., individuals living in districts without a JIC at the time of potential treatment) might actually have visited a JIC in another district. Hence, if positive treatment effects of visiting a job information center are found for educational choices and labor market outcomes in the Full Sample and the Reduced Sample I, the estimates might be lower bounds, since some individuals in the comparison group might also have been treated. The key advantage of the Reduced Sample II is that the definition of the comparison group is likely to be "cleaner". This is because the comparison group only consists of individuals from districts where a JIC eventually opened, but was not in existence when they went to school.

Table 2 presents summary statistics for the key variables by sample and treatment status. For each variable and sample, we also present $\mathrm{p}$-values for treatment and control differences. The upper panel in Table 2 reports the summary statistics for the outcome measures, and the lower panel for selected explanatory variables. There are significant differences in the unconditional means for many outcome variables between treated and non-treated individuals. For example, among those who grew up in a district with a JIC, a lower proportion completed their schooling by obtaining the lowest school degree, compared to those who grew up in a district without a JIC. The difference of five to seven percentage points is statistically significant at the one percent level in all three samples. In addition, a larger proportion of the individuals treated received the highest school degree and experienced educational upward mobility. However, the unconditional means also point toward a higher likelihood of experiencing unemployment and a slightly longer unemployment duration (0.5 to 1.2 months), on average, among treated individuals during their first five years after entering the labor market. In Section III above, it was pointed out that one resolution of the council of the Federal Employment Agency was that JICs should open in 
large cities first. In line with this decision, the mean comparisons for the explanatory variable population density at the bottom of the table shows a significantly higher population density among the treatment group than the comparison group. Moreover, there is a higher proportion of individuals with a migrant background or with a higher socio-economic background (e.g., mother or father has an upper-track school degree) among treated than non-treated individuals.

\section{Estimation Method}

To estimate the effect of the availability of job information centers on individuals' educational choices and long-term labor market outcomes, their openings are treated as a quasi-natural experiment in a difference-in-differences setup, thus making use of both regional and time variation in the availability of JICs. The estimation equation takes on the form

$$
y_{i d t}=\alpha+\beta J I C_{i d t}+\sum \lambda_{\text {district }}+\sum \phi_{b i r t h}+\sum \delta_{\text {track }}+X_{i} \gamma+X_{d} \pi+\varepsilon_{i},
$$

where $y_{i d t}$ is one of the outcome variables for individual $i$ who lived in district $d$ in the year of the potential treatment $t . J I C_{i d t}$ is an indicator variable for JIC availability equal to one if district $d$ at time $t$ had a job information center, and zero otherwise. $\sum \lambda_{\text {district }}$ captures 413 district fixed effects, $\sum \phi_{\text {birth }}$ captures 22 birth cohort fixed effects, $\sum \delta_{\text {track }}$ are fixed effects of the school track attended at the time of potential treatment, and the vector $X_{i}$ includes dummies for gender, migrant background, and parents' education. In addition, the vector $X_{d}$ consists of dummy variables capturing differences in population density between districts. This setup makes it possible to control for effects specific to treated and untreated districts (captured by $\lambda_{\text {district }}$ ) and aggregate macro trends common to all districts (captured by $\phi_{\text {birth }}$ ). The standard errors are clustered on the district level to adjust for district-specific elements in the error term.

The key parameter of interest is $\beta$. For identification, it must be ruled out that the estimates are driven by district-time-specific effects, such as reforms or regional shocks that happened at the same time and in the same regions the JICs opened. In other words, the common trend assumption must hold (cf. Section VII for evidence on this presupposition). A more precise formulation of the identifying assumption is given by the conditional independence assumption. It states that, conditional on all covariates $\mathbf{Z}=\left[\sum \lambda_{\text {district }}, \sum \phi_{\text {birth }}, \sum \delta_{\text {track }}, X_{i}, X_{d}\right]$, the potential outcomes with and without treatment, $y_{1}$ and $y_{0}$, respectively, are independent of selection into treatment: 


$$
y_{1}, y_{0} \perp T \mid \mathbf{Z}
$$

The implication of (2) is that visiting a JIC must not depend on outcomes, after controlling for the variation in outcomes induced by differences in $\mathbf{Z}$. If valid, this establishes a populationaverage treatment effect on the treated (ATT) for $\beta$. As we do not observe who among the eligible students actually visited a JIC, the ATT reduces to an average intention to treat effect. We argue that, conditional on a rich specification of district and time fixed effects as well as individual and district characteristics, the variation in the availability of JICs over time and within districts is exogenous to individuals' unobserved characteristics, such as ability, intelligence, or motivation. It is also exogenous to district-specific characteristics and common macro trends.

\section{Results}

Tables 3 to 6 report the OLS results from estimating equation (1) for different dependent variables and samples. Table 3 displays the estimates for the outcomes on education and educational mobility, Table 4 for labor market attachment, and Table 5 shows the results for job search and job matching. The estimates from wage and income regressions are reported in Table 6. Due to the high number of outcome and control variables, we only report the estimated coefficient $\beta$ and its standard errors along with the adjusted $R^{2}$ and the sample size. ${ }^{20}$ In all tables, separate results are reported for the three different samples (panels A to $\mathrm{C}$ ).

Table 3 reports the first set of results from linear probability models. ${ }^{21}$ Columns 1 to 3 show how being exposed to a job information center influences the likelihood of obtaining a certain school degree, given the school track enrolled in at potential treatment time $t$. Column 4 presents the estimates on the probability of experiencing educational upward mobility, and column 5 contains the results on the likelihood of obtaining a technical college or university degree. The estimates of panel A in Table 3 show that there is no significant effect of visiting a JIC on the likelihood of obtaining a particular school or university degree in the full sample. However, there is a positive and significant effect of visiting a JIC on the likelihood of experiencing educational upward mobility by about three percentage points.

Panels $\mathrm{B}$ and $\mathrm{C}$ in Table 3 contain the estimated results from similar specifications for individuals who attended a low- or intermediate-track school. In both panels, JIC availability

\footnotetext{
${ }^{20}$ More detailed results are shown in in Table A-3 in the Appendix.

${ }^{21}$ In unreported regressions, we also estimated logit models for all dichotomous outcome measures. The marginal effects from these models are very similar to the present OLS coefficients and are available from the authors upon request.
} 
decreases the likelihood of obtaining an intermediate-track school degree (Realschulabschluss) and increases the likelihood of a higher school qualification (Abitur). For example, a person who grows up in a district with a JIC when attending school is between 7 and 12 percentage points more likely to obtain the highest general school degree. The size of the estimated coefficients indicates that, ceteris paribus, being exposed to the job information program leads to the same increase in the likelihood of obtaining the highest general school degree as when the father has the highest school degree (Abitur) compared to a father with no school qualification. Consistent with this finding, the results in panels $\mathrm{B}$ and $\mathrm{C}$ point toward a positive and statistically significant effect on the likelihood of experiencing educational upward mobility, and the chance of obtaining a university degree. The point estimates are also in line with descriptive survey evidence among visitors to a JIC in Berlin. Schweikert and Meissner (1984) report that 21 percent of students who are attending a low-track school at the time of visiting a JIC report aiming to acquire an intermediate-track school degree (Mittlere Reife) and one percent aim to obtain the highest general school degree.

In sum, the results in Table 3 indicate a positive effect of the presence of a job information center on the likelihood of experiencing educational upward mobility, of obtaining the highest general school degree, and of successfully completing a technical college or university degree. The estimates are important from a policy perspective because it is precisely for students in lowand intermediate-track schools that educators and job counselors expect the highest potential from visiting a JIC. Students in the highest school track may already have acquired a wealth of information and knowledge from their parents or other media prior to visiting a JIC.

Next, labor market outcomes are studied. Table 4 reports estimates on the incidence and duration of part-time employment, full-time employment, and unemployment during the first five years after ending formal education. The most salient result is that being treated decreases the chances of experiencing unemployment by about eight (panels $\mathrm{A}$ and $\mathrm{C}$ ) or ten percentage points (panel B), but these effects are imprecisely estimated in all three samples. Furthermore, the results in column 5 suggest that JIC treatment increases the duration of full-time work by around 2.8 months (panel A). This effect is significantly different from zero at the five percent level. In sum, the results in Table 4 only suggest small differences in labor market attachment in the first five years of the individuals' labor market career.

Table 5 provides information about whether a visit to job information centers positively impacts on young adults' job search success and the quality of their job choice. Search duration in column 1 measures the time in months that passed between completing the last episode 
of education and beginning the first episode of regular employment. The geographic mobility measures in columns 2 and 3 of Table 5 are dichotomous outcome variables indicating whether, at the time of the interview, an individual still lives in the district or state where he or she lived while going to school. The outcome variable share involuntary job change in the last column measures the proportion of involuntary job losses in the first five years of the labor market career.

The magnitude of the estimated coefficients in column 1 of Table 5 suggest that individuals who visit a JIC spend around one to two months less searching for their first job. Note, however, that none of the estimates is different from zero at conventional significance levels. In contrast, the estimates for the likelihood of staying in the same district are precisely estimated in panels $\mathrm{A}$ and $\mathrm{B}$. The results from the linear probability models indicate that individuals who visit a JIC while young have a seven to eight percentage points higher likelihood of still living in the same district when they are adults. We interpret this as a strong effect, given that visiting a job information center positively influences individuals' education and recent research also points to a causal positive impact of education on regional labor mobility (Machin et al., 2012). Assuming that most individuals have a preference for staying in close geographic proximity to where they grow up, one possible interpretation of these results is that treated individuals experience less pressure to look for employment in distant places, since JICs help improve the quality of the matching between employers and employees in the local labor market. The estimates in column 4 of Table 5 are also consistent with an improvement in job matching. They indicate that individuals' risk of losing their job involuntary decreases significantly if they visit a job information center during their youth. The effect is strongest for individuals who attended a low- or intermediate-track school at the time of treatment.

Finally, Table 6 reports results for wage and income measures. The outcome variables in columns 1 and 2 come from the administrative data, and those in columns 3 and 4 from the survey. All outcomes in Table 6 are measured in logarithms. In addition to the control variables in the regressions in Tables 3 to 5, we add some further explanatory variables (e.g., a dummy variable for part-time employment and a maximum set of district of residence dummy variables at the time of measuring the outcome variable). ${ }^{22}$ Overall, the results in Table 6 do not suggest that visiting a job information center increases individuals' short- and long-term wages and income. For example, all estimated coefficients in panel A have a negative sign and are close

\footnotetext{
${ }^{22}$ In columns 1 and 2 of Table 6, we include a full set of district dummies at the beginning of the first job and at the age of 35, respectively. In column 3, the district dummies are measured at the last spell of employment. In column 4 , the district dummies are measured at the time of the interview.
} 
to zero. Similarly, none of the estimates in panel B are positive and statistically significant from zero at conventional levels. The only estimates pointing toward positive returns from visiting a job information center are those in panel $\mathrm{C}$ of Table 6 . However, the magnitude of the estimated effects are not very plausible and only one coefficient is significant at the five percent level. Overall, we can conclude from Table 6 that there is no convincing evidence of positive wage returns resulting from the occupational information provided by JICs in Germany.

\section{Timing of the Opening of Job Information Centers and Common Trend Assumptions}

The validity of our estimation methods requires exogeneity of the timing of the opening of job information centers. Moreover, the difference-in-differences strategy only allows an average treatment interpretation if the common trend assumption holds. We now shed further light on the validity of these identification assumptions.

In order to understand the timing of the opening of JICs, we estimated discrete-time logistic hazard models on the district-year level using rich administrative data from the SIAB. The enormous number of observations (40.5 million spells for 1.66 million individuals) makes it possible to calculate reliable district- and year-specific averages for the variables of interest. Our analysis focuses on the opening of job information centers and we treat spells (district-years) where no JIC was opened as right-censored. The sample consists of around 7,000 district-year observations, of which around 40 percent end with the opening of a JIC.

In our first model, we measure all district-level variables in the year 1975, on the eve of the opening of the first JIC in Berlin. For eastern Germany, we use the year 1992, the first year for which we have valid district-level information available. In the second model, we control for a rich set of lagged time-varying covariates. Finally, in the third model, we investigate potential correlations between changes in explanatory variables over time (e.g., percentage change between $t-2$ and $t-1)$ and the timing of the opening of job information centers.

The results are presented in Table 7. Two different specifications are presented for each model. In the first specification, we control for the log population size and the log area size of the districts, average wages, the proportions of the population with a certain school qualification, and the unemployment rate. In the second specification, various labor market characteristics for young individuals aged 25 to 30 were also included to capture differences in local labor markets across districts (and over time). Overall, the estimates show that there is no systematic and statistically significant relationship between the timing of the opening of job information centers 
and average wages, various educational levels, and the unemployment rate. Further, none of the local labor market characteristics are significantly related to the hazard of opening a JIC. The only explanatory variables that are statistically significantly related to the hazard of opening a JIC at the one percent level are the population and the size of the district. The estimates suggest that districts with a larger population have a higher hazard, and districts with a larger surface area, i.e., rural areas, have a lower hazard of opening a JIC. These results are in line with the decision by the Federal Employment Agency to open JICs in urban areas first. Overall, we interpret the results in Table 7 as strong supportive evidence for the identification strategy that the variation in the timing of the opening is unlikely to be endogenous. However, it should be pointed out that unobservable regional shocks coinciding with the timing of the opening could still bias the estimates.

Next, comprehensive graphical evidence on the common trend assumption are presented in Figures 3 to 6 . The common trend assumption states that, in the absence of treatment, the outcome variables would have parallel trends for the treatment and control group. This implies that in the years before the introduction of a job information center, districts that were eventually treated and districts that were never treated must display the same trend in the average values of the outcome variables. However, since the JICs opened at different points in time, there is no single cut-off point to separate pre-treatment and post-treatment years. The further we move along the time axis in, for example, Figure 3, the fewer districts, in which a JIC opened at some later stage, actually remain untreated at the observation time. Conversely, moving backwards on the time axis increases the number of yet untreated districts in the treatment group. The calculation of the averages becomes more precise, but as the number of pre-treatment years decreases, the graph becomes less informative. Figures 3 to 6 deal with this trade-off by comparing pre-treatment trends using three different cut-off years $(1980,1985$, and 1990, as indicated by the vertical lines). For the year 1980, for example, the solid red line shows the pre-treatment trend in outcome variables for all 130 districts $(c=130)$ where a job information center opened in 1980 or later. Analogously, the solid red line for the year 1990 represents the pre-treatment trend for the smaller sample of 41 districts $(c=41)$ that opened a JIC in 1990 or later. The blue solid line always shows the trend in the average outcomes among all districts in which a JIC never opened.

Ideally, Figures 3 to 6 would present graphs for all outcome variables. However, while its sample size is large, the SIAB only contains a limited number of variables. It allows us to draw graphs of common trends for the school and university qualification measures, labor 
market behavior at the beginning of the employment career (part-time employment, full-time employment and unemployment experiences at ages 25 to 30), unemployment rates, and wages. For example, panels (a)-(c) in Figure 3 show the development in the proportion of individuals with a low- or intermediate-track school degree between 1975 and 2008. The figure shows the pre-treatment trends (solid line) and post-treatment trends (dotted line) for the treatment group (red) and control group (blue) for the cut-off years 1980, 1985, and 1990, respectively. Figure 3 shows the trends for the educational variables, and Figure 4 for the variables duration in part-time employment, full-time employment, and unemployment (in months) at ages 25 to 30. Figure 5 displays the trends for the unemployment rate and youth unemployment rate (ages 20 to 25 ), and Figure 6 shows the development of average wages separately for the treatment and comparison group. ${ }^{23}$

Overall, the trends in the outcome variables between treatment and comparison group are quite similar. In particular, Figures 5 and 6 make the case not only for the common trend assumption (same trend) but also for same levels. For example, all panels in Figure 5 show an almost identical development of the overall unemployment rate and the youth unemployment rate over time in treated and untreated districts before and after the treatment. Therefore, it appears that the unemployment rate was not a driving factor in policy makers' decision where and when to open job information centers. In sum, we argue that the common trend assumption is likely to hold.

\section{Sensitivity Checks}

In Table 8, we explore the sensitivity of the results. For the sake of brevity, we only report estimates for selected outcome variables based on the Restricted Sample I. We begin by investigating whether the key results hold for important subgroups in the population, i.e., western Germany, rural areas, and early cohorts. Further, we examine whether there are heterogeneous effects by gender.

Panel A of Table 8 presents results for individuals living in western Germany. Overall, the estimates are quite similar to those in Tables 3 to 6 . For instance, the estimate for the outcome

\footnotetext{
${ }^{23}$ Note that the vertical lines are more informative for displaying pre-treatment rather than post-treatment levels. This is because they indicate the first year in which districts of the treatment group potentially could have been treated. As we move from the vertical line to the right, however, the number of treated districts increases only gradually. Hence, the first observations to the right of the dotted red line are characterized by a relative low treatment intensity. Moreover, the vertical lines are mainly informative for displaying trends on the county, rather than on the individual level, because there might be a time gap between treatment and realization of the outcome.
} 
upward mobility in Table 3, panel B, suggests that growing up in a district with a job information center increases the probability of experiencing upward educational mobility by 7.5 percentage points, compared to 8.3 percentage points in panel A, Table 8. One notable exception is the finding for the outcome low-track school degree. In the sample for western Germany, the point estimates suggest a statistically significant reduction in the likelihood of leaving school with the lowest school degree by eight percentage points. The corresponding estimate in the overall sample is $-0.005 .^{24}$

It was mentioned in Section III above that one of the agreements of the Federal Employment Agency, when deciding to establish JICs, was that they should first open in large cities. Hence, there is the risk that our estimates might be driven by differential time trends between urban and rural areas. To examine this, panel B in Table 8 presents estimates excluding urban districts from the regressions. ${ }^{25}$ This decreases the sample size by around 30 to 35 percent. However, the sign and magnitude of the estimates in panel $\mathrm{B}$ is in line with the corresponding results in Tables 3 to 6 . This suggests that the findings are unlikely to be driven by differential unobserved trends between rural and urban areas.

Figure 2 shows that the timing of the opening of job information centers was geographically balanced, with the exception that a JIC opened in almost all districts in the Ruhr area. Hence, we investigate whether some of the effects differ once we exclude districts in the Ruhr area. The estimates in panel $\mathrm{C}$ of Table 8 do not change much as a result of this sample restriction, suggesting that the findings are unlikely to be driven by unobserved local influences in that region. $^{26}$

Job information centers in Germany opened over a long period of time, spanning more than 20 years. Clearly, one very important innovation in these two decades was the introduction and dispersion of the Internet. Hence, visiting a JIC might be less beneficial or important for educational and occupational choices if young people were able to do Internet research. We therefore examine the impact for early cohorts, who made their educational and occupational decisions when access to the Internet was very unlikely or restricted (i.e., those born between 1960 and 1975). The results in panel D in Table 8 show that most of the effects are indeed

\footnotetext{
${ }^{24}$ In unreported regressions, we also estimated the regressions only for individuals with German nationality. The estimates were very similar to those in panel A of Table 8. Note that we do not present separate regressions for eastern Germany because of small sample sizes.

${ }^{25}$ The data allows us to distinguish between the following types of administrative districts: (1) rural districts (Landkreise); (2) districts (Kreise); (3) Free Hanseatic City (Freie Hansestadt), (4) urban municipalities (kreisfreie Städte); and (5) city boroughs (Stadtkreise und Stadtverbände). In the present sample, we exclude district types (3) to (5).

${ }^{26}$ The estimates are also unaffected if we exclude both urban districts and the districts in the Ruhr area.
} 
larger in magnitude and significance among the older cohorts. For example, the estimate on the outcome variable university degree suggests that the likelihood of obtaining a technical college or university degree increased by 12 percentage points among those born between 1960 and 1975, compared to seven percentage points in Table $3 .^{27}$

Next, we explore the sensitivity of the estimates to various econometric specifications. In panel $\mathrm{E}$ in Table 8 we also control for an additional linear time trend. This does not change the estimates considerably. Panel F reports estimates when we restrict the sample to individuals for whom the potential treatment years are within a range of 10 years around the opening of a JIC and also control for decade-state interaction terms. Again, the results are in line with the previous findings in Tables 3 to 6 .

The key identification assumption embodied in the estimation is that there were no other changes at the time JICs opened, relative to the areas where there were no JICs, that also influenced individuals' educational choices and labor market outcomes. In panel G, we test for the identification assumption with a falsification exercise. We estimate placebo regressions by moving the year of the opening of JICs forward six years. If our identification strategy is valid, then the measure for the availability of a JIC should have no impact on the various outcomes, since the individuals already made the educational choice many years before the JIC opened. Indeed, none of the point estimates in panel $\mathrm{G}$ of Table 8 is different from zero at conventional significance levels. Moreover, the magnitude of most estimates is considerably lower compared to those in Tables 3 to 6 .

In sum, the various robustness exercises confirm that the opening and availability of job information centers impacts on individuals' educational choices and influences their labor market outcomes to some extent. The results are robust to various sample selections and different econometric specifications.

\section{Conclusions}

In 1976, the German Federal Employment Agency opened its first job information center in West Berlin. Since then, 181 job information centers have opened throughout Germany. This paper quantifies the effects of the public and free provision of occupational knowledge through JICs on young adults' educational choices and labor market outcomes. More specifically, it assesses the argument of educators and policy makers that the provision of information on job

\footnotetext{
${ }^{27}$ In unreported regressions, we also estimated the regressions for individuals born between 1975 and 1982. None of the point estimates were precisely estimated for these younger cohorts.
} 
types, employment prospects, earning profiles, and educational pathways to various occupations improves the quality of educational and labor market choices.

We exploit the variation across time and regions of the opening of job information centers in Germany using a difference-in-differences strategy. Our estimates suggest that individuals, who went to a low- or intermediate-track school when a JIC was available in their district of residence, have a significantly higher probability of obtaining the highest school degree, and of experiencing upward educational mobility. Those who grow up in an administrative district with a JIC are also less likely to become unemployed, or to involuntarily lose their job in the first five years after entering the labor market. Moreover, as adults, they have a higher likelihood of still living in the same district and federal state where they lived when at school. However, no empirical evidence was found that the information program significantly increased individuals' wages and income.

Our findings point toward improved welfare gains in the short-run, since people's upward educational mobility has been increased. However, the long-term impact of the information program is rather mixed. There is some evidence of improved job match quality, but no positive impact on wages and income. Overall, the results reveal the importance of policies that promote occupational information for young people's educational choices. As countries such as Finland and Luxembourg are considering implementing similar information programs-and Australia, Austria, and Switzerland also opened job information centers in the last two decades (Hirsch, 1974; Gödl, 1986; Nowak, 1996)-our findings provide useful insights that might guide future educational and vocational policy decisions. 


\section{Figures and Tables}

Figure 1: Development of Job Information Centers in West(ern) and Eastern Germany, by Year

(a) Number of JICs

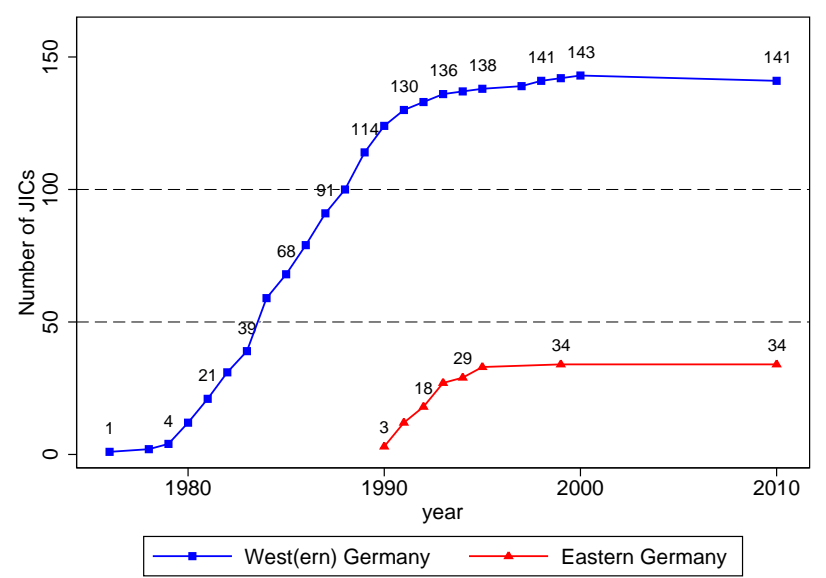

(b) Percentage of districts with a JIC

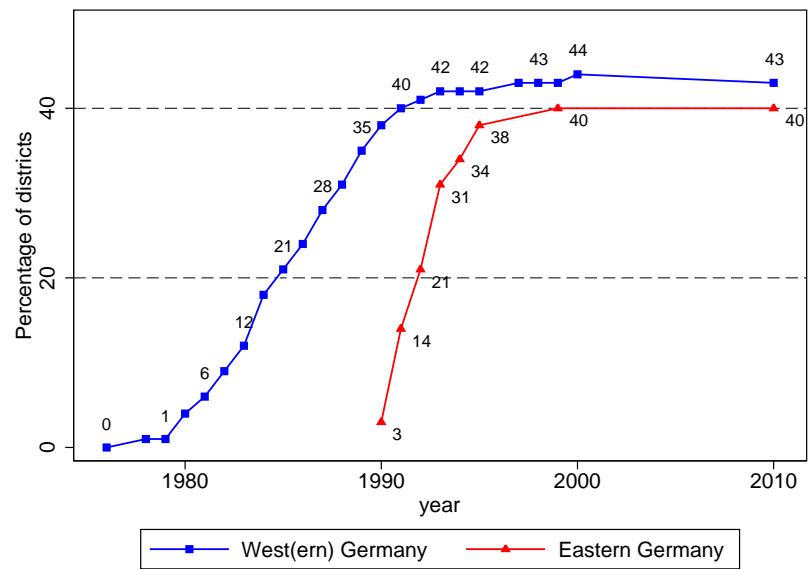

Note: Own data collection. Since the mid-1970s, 181 job information centers have opened in Germany, of which 147 opened in West/western Germany, and 34 in eastern Germany. In Berlin, two out of six JICs closed in 2005 and 2006. For four JICs (Neumünster, Coesfeld, Kassel and Saarbrücken) no data on the opening year are available. This results in 141 JICs in western Germany, and 34 in eastern Germany in 2010, respectively, as shown in panel (a). Panel (b) is based on 413 districts in the whole of Germany in 2008, of which 327 were in western Germany and 86 in eastern Germany. Berlin is defined as western Germany. 
Figure 2: Regional Distribution of Job Information Centers in Germany, on the District Level

(a) 1980

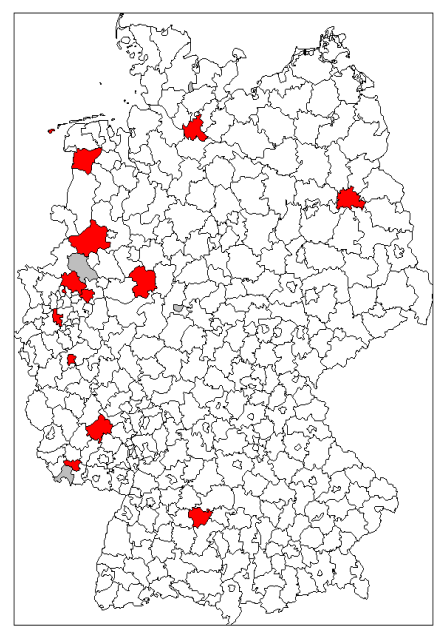

(d) 1995

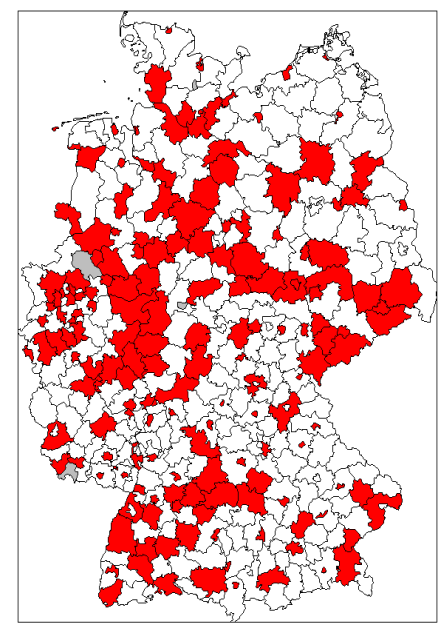

(b) 1985

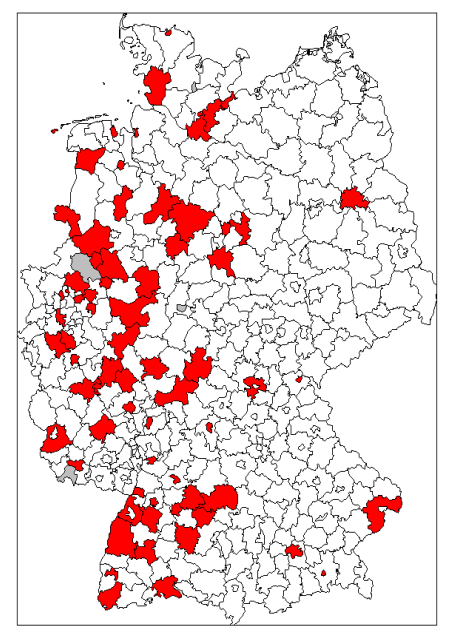

(e) 2000

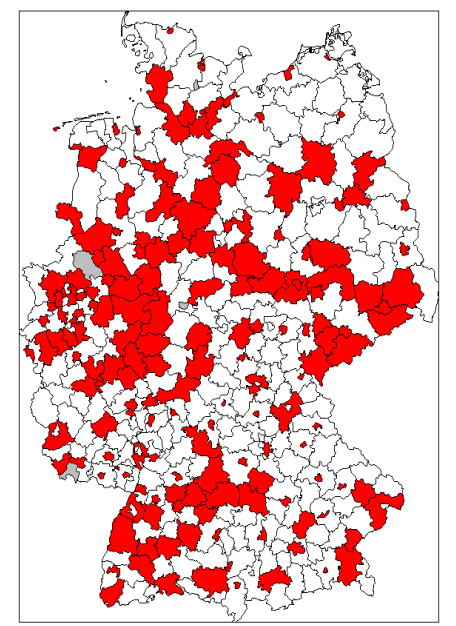

(c) 1990

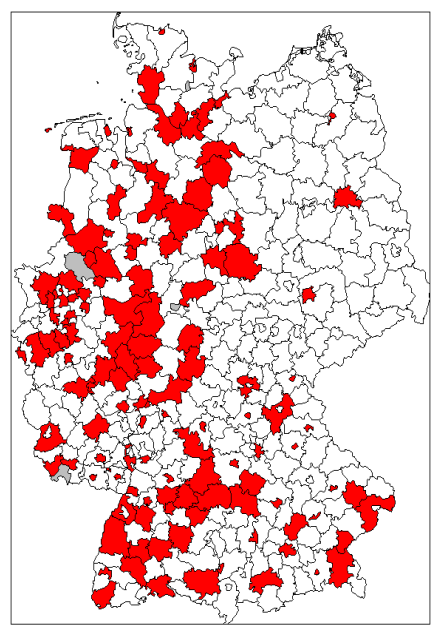

$\square$ no JIC

$\square$ JIC

$\square$ no information on opening year

Note: Own data collection. The maps are based on the shapefile VG250 provided by the Federal Agency for Cartography and Geodesy. Its administrative borders are as of December 31, 2008. 


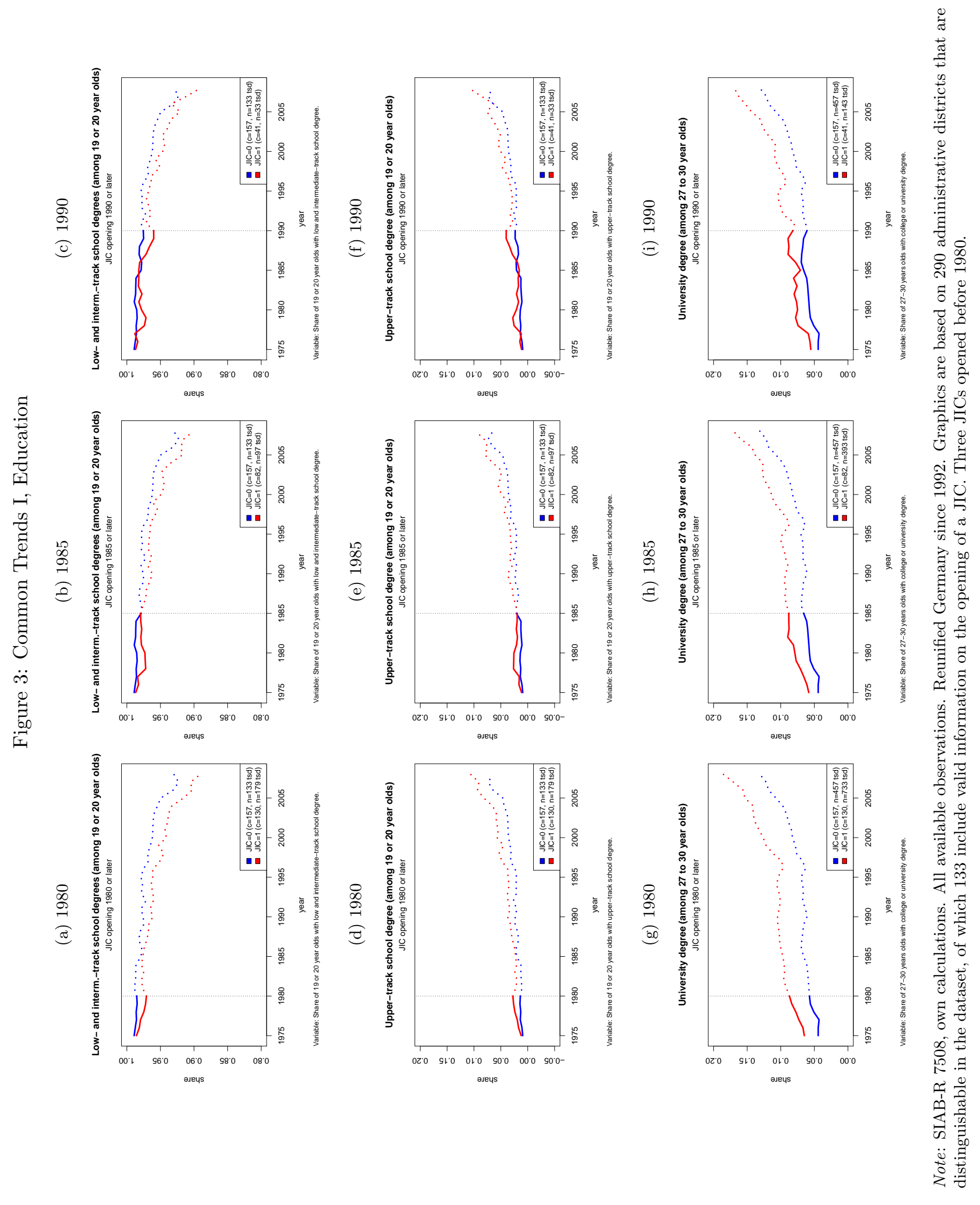




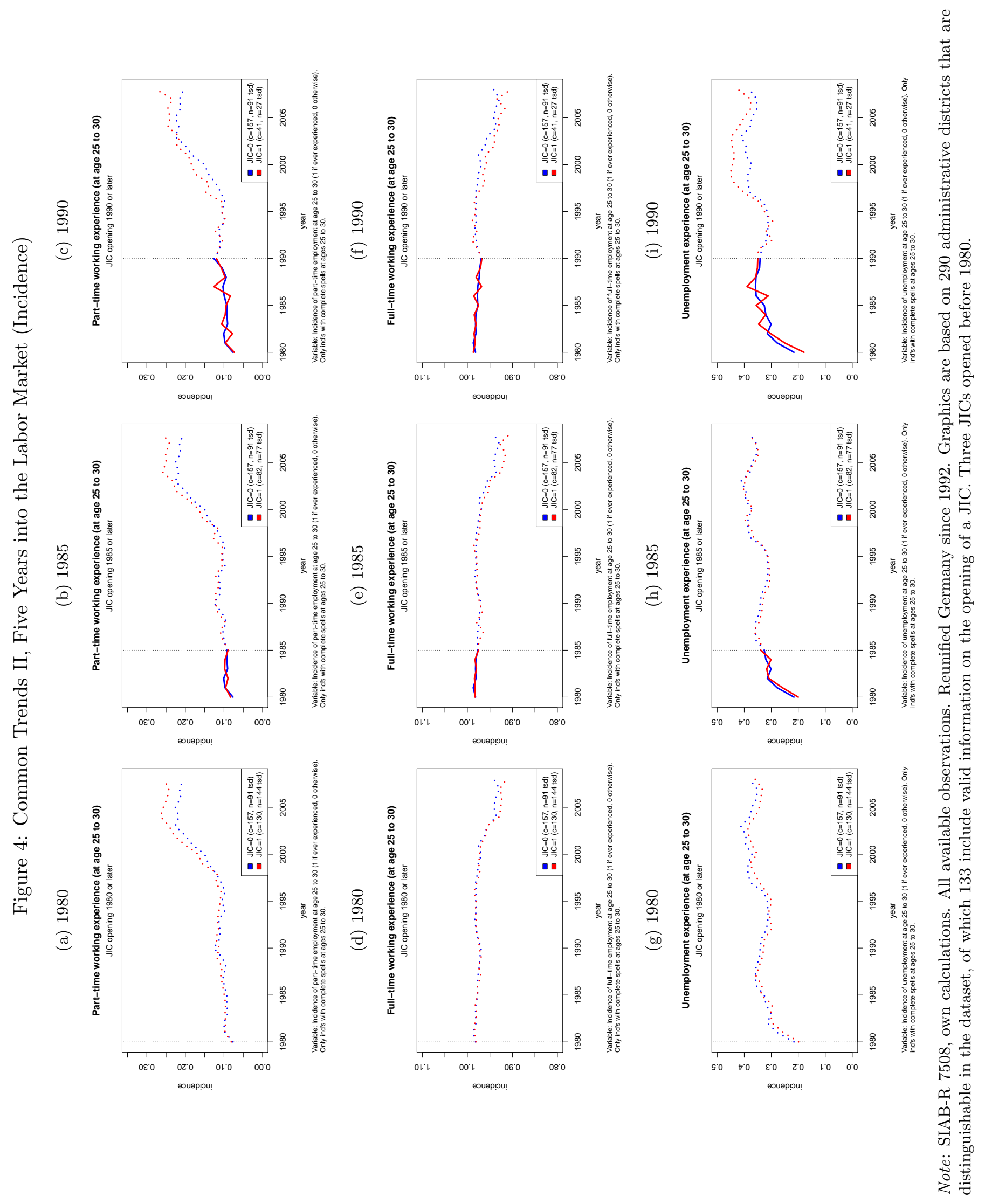




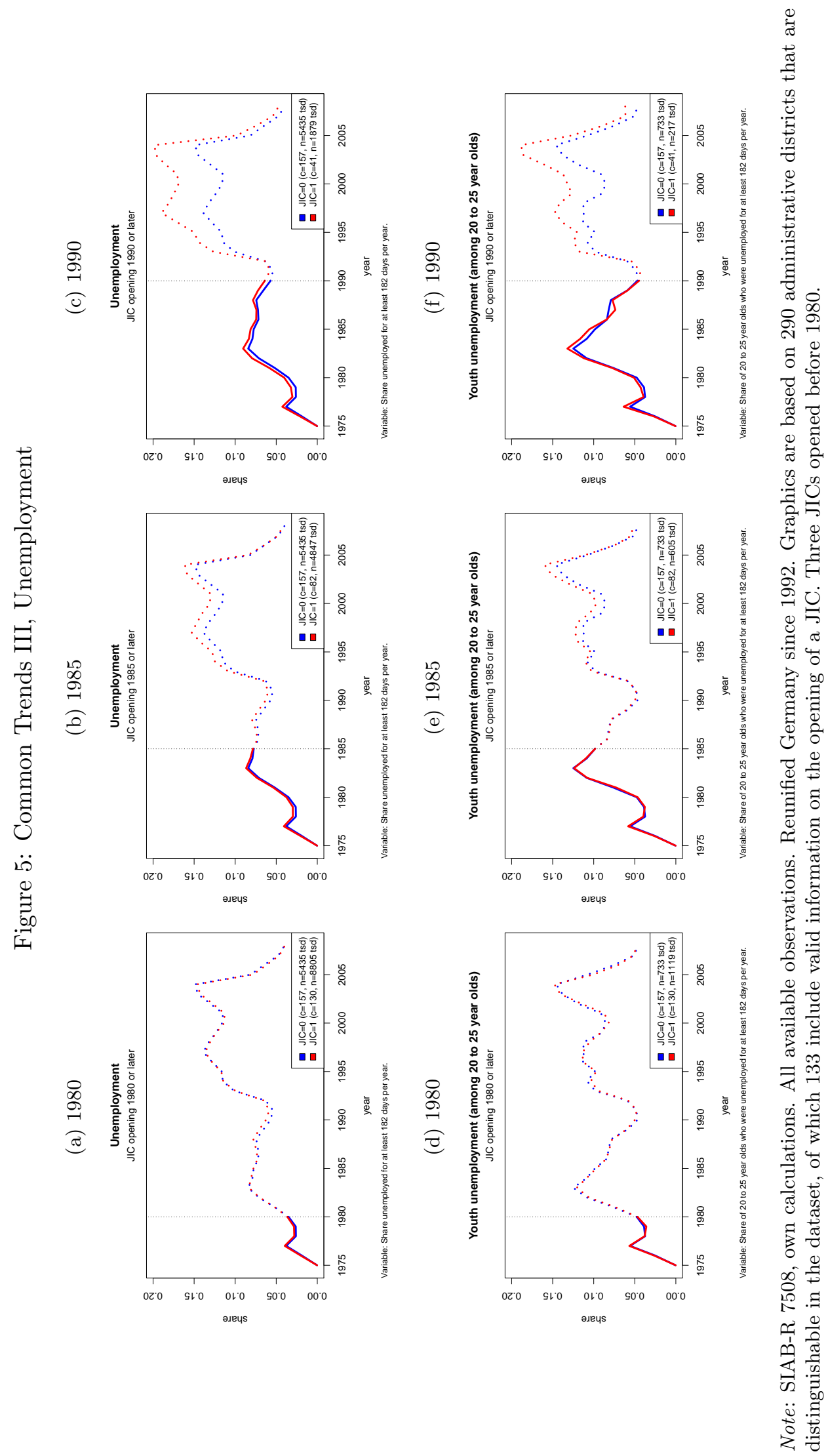




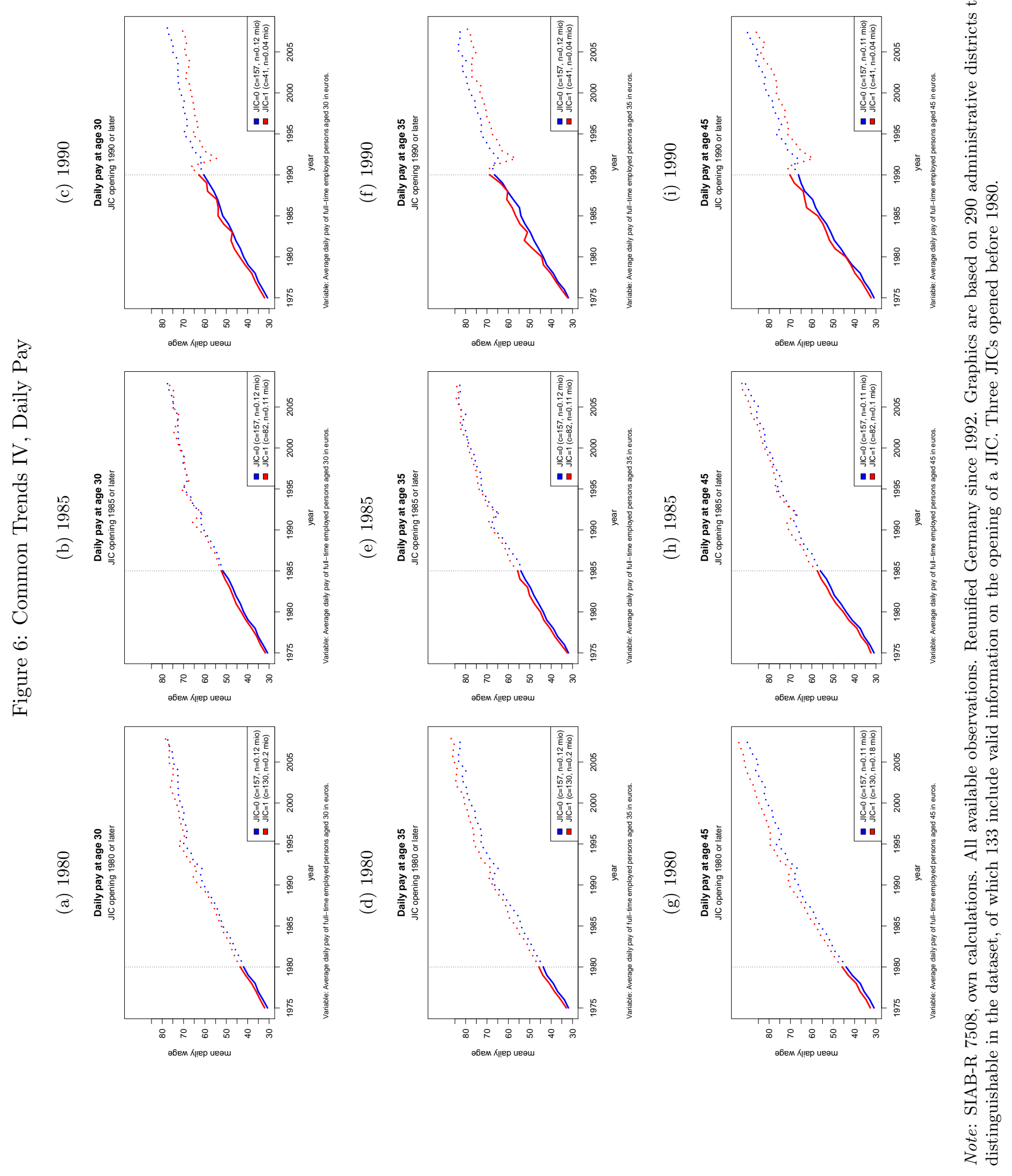


Table 1: Survey about the Increase in Knowledge

I now know more about ...

Percentage of

respondents

which school-leaving certificate you need for a particular occupation.

how the apprenticeship is structured and what you have to do in it.

how many places are available in the training program.

what you earn during an apprenticeship or how much the training costs.

which physical and mental capabilities one ought to have to go into this field.

what the workplace is like and what the job consists of.

how much you earn after training.

what kind of stress you can encounter in this field (dust, noise, and health risks).

which higher-level occupations one can obtain qualifications for through further training. 


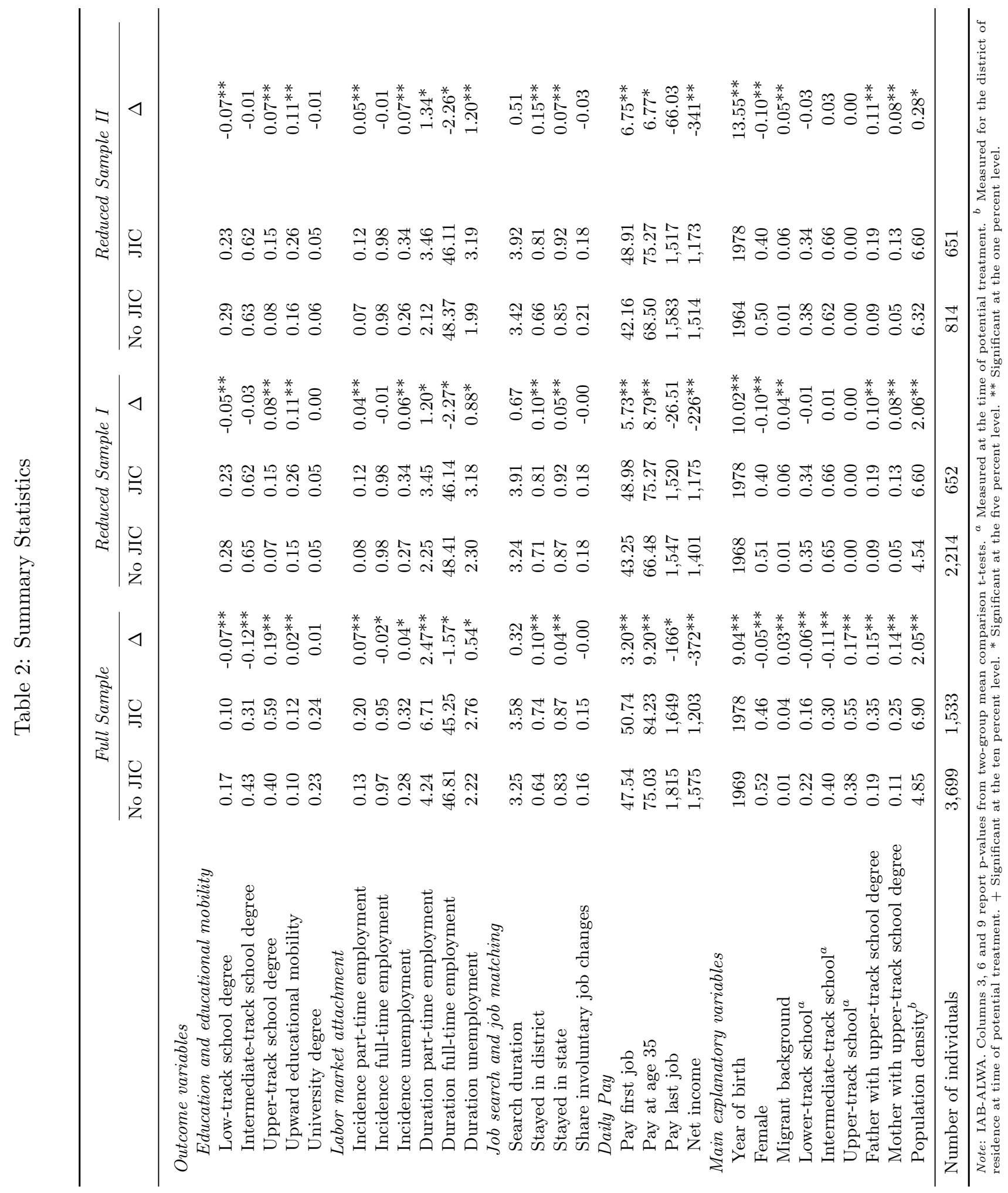


Table 3: Education and Educational Mobility

\begin{tabular}{|c|c|c|c|c|c|}
\hline Dependent variable: & $\begin{array}{c}\text { Low-track } \\
\text { school degree } \\
\text { (1) }\end{array}$ & $\begin{array}{l}\text { Interm.-track } \\
\text { school degree } \\
\text { (2) }\end{array}$ & $\begin{array}{c}\text { Upper-track } \\
\text { school degree } \\
(3)\end{array}$ & $\begin{array}{l}\text { Upward } \\
\text { mobility } \\
(4)\end{array}$ & $\begin{array}{c}\text { University } \\
\text { degree } \\
(5)\end{array}$ \\
\hline \multicolumn{6}{|c|}{ Panel A: Full sample } \\
\hline Job information center & $\begin{array}{l}-0.004 \\
(0.014)\end{array}$ & $\begin{array}{l}-0.015 \\
(0.019)\end{array}$ & $\begin{array}{c}0.019 \\
(0.014)\end{array}$ & $\begin{array}{l}0.033^{*} \\
(0.014)\end{array}$ & $\begin{array}{c}0.032 \\
(0.021)\end{array}$ \\
\hline Adjusted $\mathrm{R}^{2}$ & 0.595 & 0.563 & 0.734 & 0.154 & 0.344 \\
\hline Number of individuals & 5,232 & 5,232 & 5,232 & 5,232 & 4,972 \\
\hline \multicolumn{6}{|c|}{ Panel B: Reduced sample I } \\
\hline Job information center & $\begin{array}{l}-0.005 \\
(0.028)\end{array}$ & $\begin{array}{c}-0.064^{+} \\
(0.034)\end{array}$ & $\begin{array}{c}0.069^{* *} \\
(0.023)\end{array}$ & $\begin{array}{c}0.075^{* *} \\
(0.029)\end{array}$ & $\begin{array}{l}0.054^{* *} \\
(0.021)\end{array}$ \\
\hline Adjusted $\mathrm{R}^{2}$ & 0.544 & 0.362 & 0.055 & 0.093 & 0.065 \\
\hline Number of individuals & 2,866 & 2,866 & 2,866 & 2,866 & 2,737 \\
\hline \multicolumn{6}{|c|}{ Panel C: Reduced sample II } \\
\hline Job information center & $\begin{array}{l}-0.025 \\
(0.031)\end{array}$ & $\begin{array}{c}-0.095^{*} \\
(0.042)\end{array}$ & $\begin{array}{l}0.120^{* *} \\
(0.035)\end{array}$ & $\begin{array}{l}0.121^{* *} \\
(0.039)\end{array}$ & $\begin{array}{l}0.108^{* *} \\
(0.036)\end{array}$ \\
\hline Adjusted $\mathrm{R}^{2}$ & 0.491 & 0.318 & 0.094 & 0.114 & 0.080 \\
\hline Number of individuals & 1,465 & 1,465 & 1,465 & 1,465 & 1,387 \\
\hline
\end{tabular}

Note: ALWA-ADIAB. OLS regressions. Each estimate represents the coefficient from a different regression. Standard errors (in parentheses) are clustered on the district level. All specifications control for a female and migrant dummy, dummies for year of birth, dummies for district of residence and school track attended at time of potential treatment, dummies for mothers' and fathers' highest school qualification, and dummies for population density on the district level at time of potential treatment (10 groups). See Table A-3 in the Appendix for detailed regression output. Reduced sample I only includes individuals in low- and intermediate-track schools (Hauptschule and Realschule) at the time of potential treatment. Reduced sample II consists of Reduced Sample I individuals, but only those who lived at the time of potential treatment in districts in which a job information center opened between 1976 and 2010. + Significant at the ten percent level. * Significant at the five percent level. ${ }^{* *}$ Significant at the one percent level. 
Table 4: Labor Market Attachment

\begin{tabular}{|c|c|c|c|c|c|c|}
\hline \multirow[b]{2}{*}{ Dependent variable: } & \multicolumn{3}{|c|}{ Incidence (yes/no) } & \multicolumn{3}{|c|}{ Duration (months) } \\
\hline & $\begin{array}{c}\text { Part-time } \\
\text { employed } \\
\text { (1) }\end{array}$ & $\begin{array}{c}\text { Full-time } \\
\text { employed } \\
(2)\end{array}$ & $\begin{array}{c}\text { Unem- } \\
\text { ployment } \\
(3)\end{array}$ & $\begin{array}{c}\text { Part-time } \\
\text { employed } \\
(4)\end{array}$ & $\begin{array}{c}\text { Full-time } \\
\text { employed } \\
(5)\end{array}$ & $\begin{array}{c}\text { Unem- } \\
\text { ployment } \\
(6)\end{array}$ \\
\hline \multicolumn{7}{|c|}{ Panel A: Full sample } \\
\hline Job information center & $\begin{array}{l}-0.010 \\
(0.028)\end{array}$ & $\begin{array}{l}-0.010 \\
(0.014)\end{array}$ & $\begin{array}{c}-0.077^{+} \\
(0.041)\end{array}$ & $\begin{array}{c}0.056 \\
(1.157)\end{array}$ & $\begin{array}{l}2.811^{*} \\
(1.257)\end{array}$ & $\begin{array}{c}-0.658 \\
(0.547)\end{array}$ \\
\hline Adjusted $\mathrm{R}^{2}$ & 0.095 & 0.034 & 0.043 & 0.088 & 0.046 & 0.021 \\
\hline Number of individuals & 3,286 & 3,286 & 3,359 & 3,286 & 3,286 & 3,359 \\
\hline \multicolumn{7}{|c|}{ Panel B: Reduced Sample I } \\
\hline Job information center & $\begin{array}{c}0.008 \\
(0.033)\end{array}$ & $\begin{array}{c}0.009 \\
(0.016)\end{array}$ & $\begin{array}{c}-0.101^{+} \\
(0.055)\end{array}$ & $\begin{array}{c}0.083 \\
(1.285)\end{array}$ & $\begin{array}{c}1.541 \\
(1.613)\end{array}$ & $\begin{array}{l}-0.767 \\
(0.679)\end{array}$ \\
\hline Adjusted $\mathrm{R}^{2}$ & 0.053 & 0.017 & 0.080 & 0.007 & 0.027 & 0.052 \\
\hline Number of individuals & 2,160 & 2,160 & 2,198 & 2,160 & 2,160 & 2,198 \\
\hline \multicolumn{7}{|c|}{ Panel C: Reduced Sample II } \\
\hline Job information center & $\begin{array}{l}-0.030 \\
(0.040)\end{array}$ & $\begin{array}{c}0.006 \\
(0.018)\end{array}$ & $\begin{array}{c}-0.080 \\
(0.071)\end{array}$ & $\begin{array}{c}-1.183 \\
(1.750)\end{array}$ & $\begin{array}{c}2.390 \\
(2.122)\end{array}$ & $\begin{array}{l}-0.061 \\
(0.645)\end{array}$ \\
\hline Adjusted $\mathrm{R}^{2}$ & 0.075 & 0.045 & 0.069 & 0.029 & 0.007 & 0.054 \\
\hline Number of individuals & 1,075 & 1,075 & 1,094 & 1,075 & 1,075 & 1,094 \\
\hline
\end{tabular}

Note: ALWA-ADIAB. OLS regressions. Each estimate represents the coefficient from a different regression. Standard errors (in parentheses) are clustered on the district level. All specifications control for a female and migrant dummy, dummies for year of birth, dummies for district of residence and school track attended at time of potential treatment, dummies for mothers' and fathers' highest school qualification, and dummies for population density on the district level at time of potential treatment (10 groups). See Table A-3 in the Appendix for detailed regression output. Reduced sample I only includes individuals in low- and intermediate-track schools (Hauptschule and Realschule) at the time of potential treatment. Reduced sample II consists of Reduced Sample I individuals, but only those who lived at the time of potential treatment in districts in which a job information center opened between 1976 and 2010. + Significant at the ten percent level. * Significant at the five percent level. ${ }^{* *}$ Significant at the one percent level. 
Table 5: Job Search and Job Matching

\begin{tabular}{|c|c|c|c|c|}
\hline & $\begin{array}{c}\text { Search } \\
\text { duration } \\
\quad(1)\end{array}$ & $\begin{array}{c}\text { Stayed } \\
\text { in district } \\
(2)\end{array}$ & $\begin{array}{c}\text { Stayed } \\
\text { in state } \\
(3)\end{array}$ & $\begin{array}{c}\text { Share invol. } \\
\text { job changes } \\
(4)\end{array}$ \\
\hline \multicolumn{5}{|c|}{ Panel A: Full sample } \\
\hline Job information center & $\begin{array}{l}-0.968 \\
(0.801)\end{array}$ & $\begin{array}{c}0.072^{* *} \\
(0.025)\end{array}$ & $\begin{array}{c}0.027 \\
(0.019)\end{array}$ & $\begin{array}{c}-0.051^{+} \\
(0.027)\end{array}$ \\
\hline Adjusted $\mathrm{R}^{2}$ & 0.001 & 0.242 & 0.181 & 0.034 \\
\hline Number of individuals & 3,366 & 5,213 & 5,215 & 2,427 \\
\hline \multicolumn{5}{|c|}{ Panel B: Reduced sample I } \\
\hline Job information center & $\begin{array}{l}-1.431 \\
(1.016)\end{array}$ & $\begin{array}{c}0.082^{*} \\
(0.032)\end{array}$ & $\begin{array}{l}0.040^{+} \\
(0.022)\end{array}$ & $\begin{array}{c}-0.079^{+} \\
(0.044)\end{array}$ \\
\hline Adjusted $\mathrm{R}^{2}$ & 0.048 & 0.244 & 0.223 & 0.007 \\
\hline Number of individuals & 2,205 & 2,864 & 2,864 & 1,479 \\
\hline \multicolumn{5}{|c|}{ Panel B: Reduced sample II } \\
\hline Job information center & $\begin{array}{l}-1.821 \\
(1.503)\end{array}$ & $\begin{array}{c}0.018 \\
(0.045)\end{array}$ & $\begin{array}{c}0.012 \\
(0.032)\end{array}$ & $\begin{array}{r}-0.123^{+} \\
(0.063)\end{array}$ \\
\hline Adjusted $\mathrm{R}^{2}$ & 0.096 & 0.202 & 0.133 & 0.016 \\
\hline Number of individuals & 1,098 & 1,463 & 1,463 & 731 \\
\hline
\end{tabular}

Note: ALWA-ADIAB. OLS regressions. Each estimate represents the coefficient from a different regression. Standard errors (in parentheses) are clustered on the district level. All specifications control for a female and migrant dummy, dummies for year of birth, dummies for district of residence and school track attended at time of potential treatment, dummies for mothers' and fathers' highest school qualification, and dummies for population density on the district level at time of potential treatment (10 groups). See Table A-3 in the Appendix for detailed regression output. Reduced sample I only includes individuals in low- and intermediate-track schools (Hauptschule and Realschule) at the time of potential treatment. Reduced sample II consists of Reduced Sample I individuals, but only those who lived at the time of potential treatment in districts in which a job information center opened between 1976 and 2010. + Significant at the ten percent level. * Significant at the five percent level. ** Significant at the one percent level. 
Table 6: Wages and Income

\begin{tabular}{|c|c|c|c|c|}
\hline \multirow[b]{2}{*}{ Dependent variable: } & \multicolumn{2}{|c|}{$\begin{array}{c}\text { Register data } \\
\text { (ALWA-ADIAB) }\end{array}$} & \multicolumn{2}{|c|}{$\begin{array}{l}\text { Survey data } \\
\text { (ALWA) }\end{array}$} \\
\hline & $\begin{array}{l}\text { Daily pay } \\
\text { first job } \\
\quad(1)\end{array}$ & $\begin{array}{c}\text { Daily pay } \\
\text { at age } 35 \\
(2)\end{array}$ & $\begin{array}{c}\text { Daily pay } \\
\text { last job } \\
(3)\end{array}$ & $\begin{array}{c}\text { Net monthly } \\
\text { income } \\
(4)\end{array}$ \\
\hline \multicolumn{5}{|c|}{ Panel A: Full sample } \\
\hline Job information center & $\begin{array}{l}-0.013 \\
(0.033)\end{array}$ & $\begin{array}{l}-0.106 \\
(0.071)\end{array}$ & $\begin{array}{l}-0.010 \\
(0.034)\end{array}$ & $\begin{array}{l}-0.003 \\
(0.040)\end{array}$ \\
\hline Adjusted $\mathrm{R}^{2}$ & 0.233 & 0.315 & 0.568 & 0.349 \\
\hline Number of individuals & 2,496 & 1,831 & 2,777 & 4519 \\
\hline \multicolumn{5}{|c|}{ Panel B: Reduced sample I } \\
\hline Job information center & $\begin{array}{c}0.002 \\
(0.043)\end{array}$ & $\begin{array}{l}-0.116 \\
(0.101)\end{array}$ & $\begin{array}{c}0.078 \\
(0.052)\end{array}$ & $\begin{array}{l}-0.046 \\
(0.057)\end{array}$ \\
\hline Adjusted $\mathrm{R}^{2}$ & 0.258 & 0.325 & 0.563 & 0.306 \\
\hline Number of individuals & 1,574 & 1,201 & 1,692 & 2,531 \\
\hline \multicolumn{5}{|c|}{ Panel C: Reduced sample II } \\
\hline Job information center & $\begin{array}{c}0.067 \\
(0.077)\end{array}$ & $\begin{array}{l}-0.125 \\
(0.124)\end{array}$ & $\begin{array}{l}0.172^{*} \\
(0.079)\end{array}$ & $\begin{array}{c}0.065 \\
(0.086)\end{array}$ \\
\hline Adjusted $\mathrm{R}^{2}$ & 0.237 & 0.260 & 0.562 & 0.330 \\
\hline Number of individuals & 812 & 611 & 859 & 1,285 \\
\hline
\end{tabular}

Note: ALWA-ADIAB. OLS regressions. Each estimate represents the coefficient from a different regression. Standard errors (in parentheses) are clustered on the district level. All specifications control for a female and migrant dummy, dummies for year of birth, dummies for district of residence and school track attended at time of potential treatment, dummies for mothers' and fathers' highest school qualification, and dummies for population density on the district level at time of potential treatment (10 groups). See Table A-3 in the Appendix for detailed regression output. Reduced sample $I$ only includes individuals in low- and intermediate-track schools (Hauptschule and Realschule) at the time of potential treatment. Reduced sample II consists of Reduced Sample I individuals, but only those who lived at the time of potential treatment in districts in which a job information center opened between 1976 and 2010. + Significant at the ten percent level. * Significant at the five percent level. ** Significant at the one percent level. Compared to the baseline specification the regressions include full sets of county dummies for the time when the monetary flow was realized. Models (1)-(3) additionally control for part-time employment, and models (1) and (2) additionally control for the number of days worked in the year of the respective age. Finally, models (3) also controls for age and age $^{2}$. 
Table 7: Discrete Time Logistic Hazard Models of Opening a Job Information Center on the District Level

\begin{tabular}{|c|c|c|c|c|c|c|}
\hline & \multicolumn{2}{|c|}{$\begin{array}{l}\text { Pre-determined } \\
\quad \text { variables }^{a}\end{array}$} & \multicolumn{2}{|c|}{$\begin{array}{l}\text { Time-varying } \\
\text { covariates }^{b}\end{array}$} & \multicolumn{2}{|c|}{$\begin{array}{l}\text { Prop. changes } \\
\text { between } \\
\text { t- } 1 \text { and } t-2^{c}\end{array}$} \\
\hline & $(1)$ & $(2)$ & $(1)$ & $(2)$ & $(1)$ & $(2)$ \\
\hline Log population $[\times 1000]$ & $\begin{array}{l}1.149^{* *} \\
(0.196)\end{array}$ & $\begin{array}{l}1.176^{* *} \\
(0.207)\end{array}$ & $\begin{array}{l}1.062^{* *} \\
(0.162)\end{array}$ & $\begin{array}{l}1.201^{* *} \\
(0.189)\end{array}$ & $\begin{array}{l}1.081^{* *} \\
(0.157)\end{array}$ & $\begin{array}{l}0.963^{* *} \\
(0.218)\end{array}$ \\
\hline Log size of area $\left[\mathrm{km}^{2}\right]$ & $\begin{array}{c}-0.477^{* *} \\
(0.109)\end{array}$ & $\begin{array}{c}-0.501^{* *} \\
(0.115)\end{array}$ & $\begin{array}{c}-0.421^{* *} \\
(0.099)\end{array}$ & $\begin{array}{c}-0.574^{* *} \\
(0.109)\end{array}$ & $\begin{array}{c}-0.465^{* *} \\
(0.090)\end{array}$ & $\begin{array}{r}-0.719^{* *} \\
(0.116)\end{array}$ \\
\hline Daily pay & $\begin{array}{l}-0.073 \\
(0.074)\end{array}$ & $\begin{array}{l}-0.106 \\
(0.069)\end{array}$ & $\begin{array}{c}0.019 \\
(0.031)\end{array}$ & $\begin{array}{c}-0.065^{+} \\
(0.034)\end{array}$ & $\begin{array}{c}7.306 \\
(8.025)\end{array}$ & $\begin{array}{l}-1.270 \\
(8.519)\end{array}$ \\
\hline Percent in the population with: & & & & & & \\
\hline low or interm.-track school degree & $\begin{array}{c}-0.406 \\
(19.228)\end{array}$ & $\begin{array}{c}14.479 \\
(24.543)\end{array}$ & $\begin{array}{c}-13.030 \\
(15.110)\end{array}$ & $\begin{array}{c}-7.180 \\
(15.928)\end{array}$ & $\begin{array}{c}-2.963 \\
(24.401)\end{array}$ & $\begin{array}{c}17.472 \\
(29.738)\end{array}$ \\
\hline upper-track school degree & $\begin{array}{c}5.717 \\
(28.338)\end{array}$ & $\begin{array}{c}31.279 \\
(33.529)\end{array}$ & $\begin{array}{l}-21.667 \\
(20.940)\end{array}$ & $\begin{array}{c}-4.889 \\
(21.399)\end{array}$ & $\begin{array}{l}-0.682 \\
(1.443)\end{array}$ & $\begin{array}{l}-0.357 \\
(2.411)\end{array}$ \\
\hline university degree & $\begin{array}{c}1.012 \\
(22.951)\end{array}$ & $\begin{array}{l}-19.240 \\
(27.139)\end{array}$ & $\begin{array}{c}17.660 \\
(15.833)\end{array}$ & $\begin{array}{c}4.252 \\
(16.028)\end{array}$ & $\begin{array}{c}0.641 \\
(1.188)\end{array}$ & $\begin{array}{c}0.191 \\
(1.932)\end{array}$ \\
\hline Unemployment rate & $\begin{array}{c}4.422 \\
(6.981)\end{array}$ & $\begin{array}{l}-2.236 \\
(6.877)\end{array}$ & $\begin{array}{l}-0.252 \\
(2.047)\end{array}$ & $\begin{array}{l}-4.890 \\
(3.298)\end{array}$ & $\begin{array}{c}0.529 \\
(0.407)\end{array}$ & $\begin{array}{c}0.670 \\
(0.602)\end{array}$ \\
\hline $\begin{array}{l}\text { Number of months (age } 25 \text { to } 30 \text { ): } \\
\text { employed full-time }\end{array}$ & & $\begin{array}{l}-0.013 \\
(0.017)\end{array}$ & & $\begin{array}{c}0.002 \\
(0.019)\end{array}$ & & $\begin{array}{c}0.245 \\
(0.344)\end{array}$ \\
\hline employed part-time & & $\begin{array}{l}-0.049 \\
(0.062)\end{array}$ & & $\begin{array}{c}0.038 \\
(0.050)\end{array}$ & & $\begin{array}{c}0.045 \\
(0.035)\end{array}$ \\
\hline unemployed & & $\begin{array}{l}-0.156 \\
(0.095)\end{array}$ & & $\begin{array}{l}-0.011 \\
(0.059)\end{array}$ & & $\begin{array}{c}0.010 \\
(0.040)\end{array}$ \\
\hline $\begin{array}{l}\text { Percentage of the population } \\
\text { (age } 25 \text { to } 30) \text { : }\end{array}$ & & & & & & \\
\hline employed full-time & & $\begin{array}{l}-2.382 \\
(3.569)\end{array}$ & & $\begin{array}{l}-1.329 \\
(2.456)\end{array}$ & & $\begin{array}{r}-3.408^{+} \\
(1.831)\end{array}$ \\
\hline employed part-time & & $\begin{array}{l}-0.662 \\
(2.154)\end{array}$ & & $\begin{array}{l}-2.394 \\
(1.571)\end{array}$ & & $\begin{array}{c}0.028 \\
(1.132)\end{array}$ \\
\hline unemployed & & $\begin{array}{l}-0.582 \\
(1.141)\end{array}$ & & $\begin{array}{c}0.200 \\
(1.102)\end{array}$ & & $\begin{array}{c}0.001 \\
(0.245)\end{array}$ \\
\hline Adjusted $R^{2}$ & 0.151 & 0.172 & 0.152 & 0.166 & 0.158 & 0.198 \\
\hline Number of district-year observations & 7,041 & 5,567 & 7,041 & 5,567 & 6,415 & 2,905 \\
\hline
\end{tabular}

Note: ADIAB (SIAB), 1975-2008. The table reports coefficients from logit models using a time-to-event dataset on the the district level. Standard errors in parentheses are corrected for clustering on the district level. Explanatory variables are averages on the district level. ${ }^{a}$ Pre-determined variables are measured in the first year available on the district level, corresponding to 1975 in West Germany and to 1992 in eastern Germany. ${ }^{b}$ Time-varying covariates vary on the annual level, except for $\log$ population and $\log$ size, due to data limitations. ${ }^{c}$ Explanatory variables measure proportionate changes between $t-2$ and $t-1$. All specifications also control for yearly duration dependence parameters. + Significant at the ten percent level. * Significant at the five percent level. ** Significant at the one percent level. 


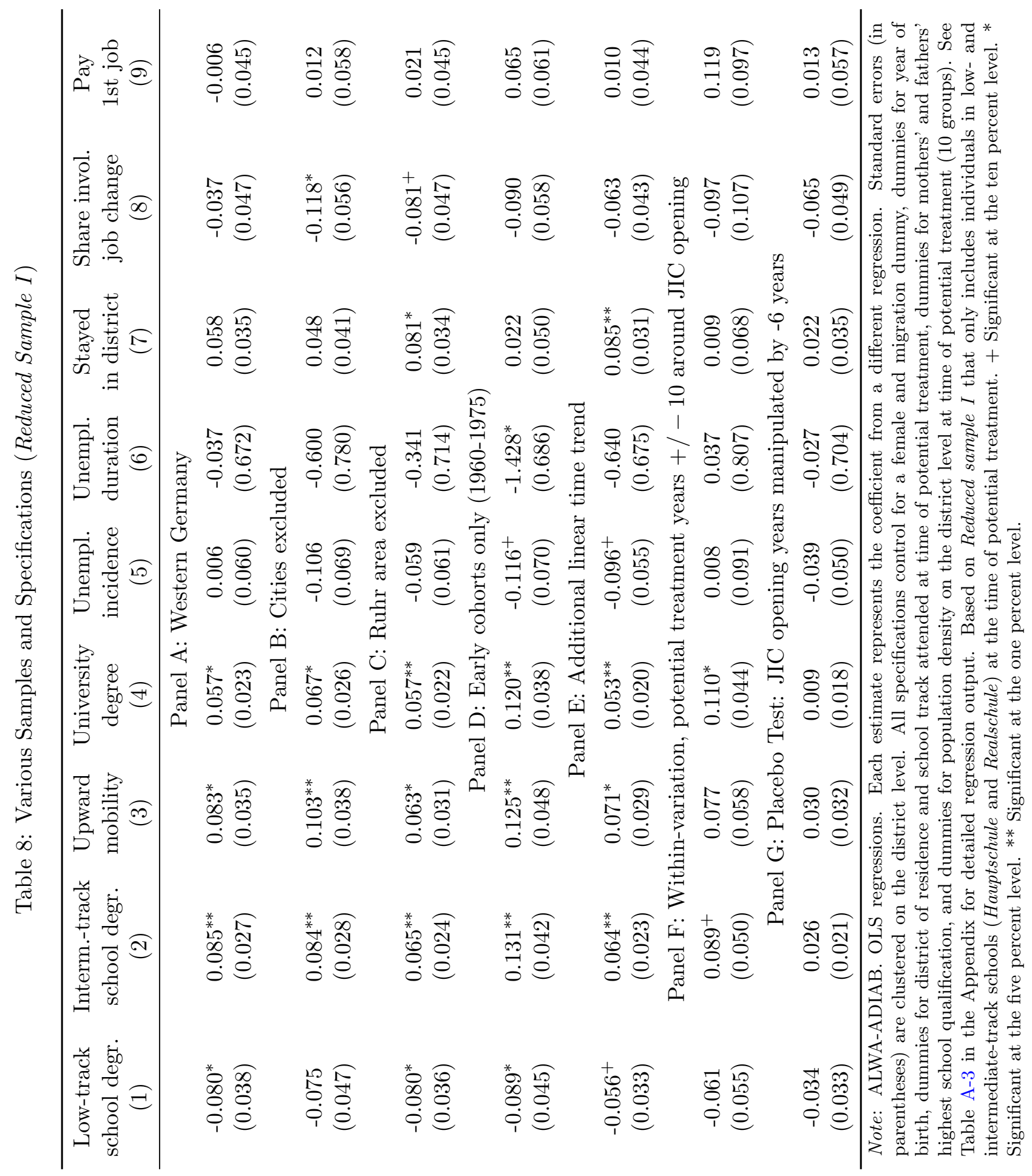




\section{References}

Akerlof, G. A. and R. E. Kranton (2000). Economics and Identity. Quarterly Journal of Economics $115(3), 715-753$.

Antoni, M., K. Drasch, C. Kleinert, B. Matthes, M. Ruhland, and A. Trahms (2011). Working and Learning in a Changing World: Part 1: Overview of the Study. FDZ-Methodenreport (05), $1-48$.

Antoni, M. and S. Seth (2011). ALWA-ADIAB - Linked Individual Survey and Administrative Data for Substantive and Methodological Research. FDZ-Methodenreport (12), 1-9.

Beinke, L. (1988). Teil A. In U. Wiegand and U. Wascher (Eds.), Berufswahl und Berufsinformation, Volume 4 of Beiträge zu: Berufsorientierung, Arbeitslehre, Erwachsenenbildung, pp. 9-64. Bad Honnef: Bock.

Booij, A. S., E. Leuven, and H. Oosterbeek (2012). The Role of Information in the Take-Up of Students Loans. Economics of Education Review 31(1), 33-44.

Borghans, L., B. H. H. Golsteyn, and A. Stenberg (2013). Does Expert Advice Improve Educational Choice? IZA Discussion Paper (7649), 1-65.

Dominitz, J. (1998). Earnings Expectations, Revisions, and Realizations. Review of Economics and Statistics $80(3), 374-388$.

Dorner, M., J. Heining, P. Jacobebbinghaus, and S. Seth (2010). Sample of Integrated Labour Market Biographies (SIAB) 1975-2008. FDZ-Datenreport (1), 1-63.

Dustmann, C. (2004). Parental Background, Secondary School Track Choice, and Wages. Oxford Economic Papers 56(2), 209-230.

Favara, M. (2012). The Cost of Acting 'Girly': Gender Stereotypes and Educational Choices. IZA Discussion Paper (7037), 1-65.

Francesconi, M., S. P. Jenkins, and T. Siedler (2010). Childhood Family Structure and Schooling Outcomes: Evidence from Germany. Journal of Population Economics 23(3), 1073-1103.

Gödl, H. (1986). Berufswahl und Berufsinformationszentrum. Ergebnisse einer empirischen Untersuchung. Berufsberatung und Berufsbildung 71(3), 153-161. 
Hainmüller, J., B. Hofmann, G. Krug, and K. Wolf (2009). Do more Placement Officers Lead to Lower Unemployment? Evidence from Germany. IAB Discussion Paper (13), 1-16.

Hastings, J. S. and J. M. Weinstein (2008). Information, School Choice, and Academic Achievement: Evidence from two Experiments. Quarterly Journal of Economics 123(4), 1373-1414.

Hermanns, K. (1989). BIZ'88. Ergebnisse einer Repräsentativbefragung von Benutzern der BIZMediotheken. Informationen für die Beratungs- und Vermittlungsdienste der Bundesanstalt für Arbeit - Nürnberg (8), 281-286.

Hermanns, K. (1992). BIZ'91. Ergebnisse der repräsentativen Befragung 1991 von Nutzern der BIZ-Mediotheken in den alten Bundesländern. Informationen für die Beratungs- und Vermittlungsdienste der Bundesanstalt für Arbeit - Nürnberg (12), 841-846.

Hirsch, W. (1974). Planung und Vorbereitung von Berufsinformationszentren der Berufsberatung. Arbeit, Beruf und Arbeitslosenhilfe. Das Arbeitsamt. Fachzeitschrift für die Aufgaben der Bundesanstalt für Arbeit 25(8), 245-249.

Jenschke, B. (1979a). Berufsberatung und Schule: Aufgaben und Möglichkeiten der Zusammenarbeit. Tübingen: Deutsches Institut für Fernstudien an der Universität Tübingen.

Jenschke, B. (1979b). Berufsinformationszentrum Berlin - Zielsetzung und Struktur: Ein Erfahrungsbericht. Wirtschaft und Berufserziehung 31(5), 133-139.

Jenschke, B. (1979c). Berufsinformationszentrum und Berufswahlunterricht. In U. J. Kledzik and B. Jenschke (Eds.), Berufswahlunterricht als Teil der Arbeitslehre, pp. 154-162. Hannover et al.: Schroedel.

Jensen, R. (2010). The (Perceived) Returns to Education and the Demand for Schooling. Quarterly Journal of Economics 125(2), 515-548.

Kretschmer, G. and D. Perrey (1998). Ergebnisse der repräsentativen Befragung 1997 von Nutzern der Berufsinformationszentren (BIZ). Informationen für die Beratungs- und Vermittlungsdienste der Bundesanstalt für Arbeit - Nürnberg (9), 727-736.

Lohmann, B. (1988). Berufsinformationszentren. Eine Idee setzt sich durch. Gewerkschaftliche Bildungspolitik 4, 124-127.

Machin, S., P. Pelkonen, and K. G. Salvanes (2012). Education and Mobility. Journal of the European Economic Association 10(2), 417-450. 
Martínez, A. and T. Dinkelman (2013). Investing in Schooling in Chile: The Role of Information about Financial Aid for Higher Education. Review of Economics and Statistics (forthcoming).

Massute, J. (1984). Berufsinformationszentren - Befragung von Besuchern. arbeit und beruf. Fachzeitschrift für die Aufgaben der Bundesanstalt für Arbeit 35(7), 196-198.

Miller, R. A. (1984). Job Matching and Occupational Choice. Journal of Political Economy 92(6), 1086-1120.

Nguyen, T. (2008). Information, Role Models and Perceived Returns to Education: Experimental Evidence from Madagascar. mimeo.

Nieder, H. (1980). Selbstinformationseinrichtungen der Berufsberatung werden ausgebaut: Ein Situationsbericht. Arbeit und Beruf (1), 4-6.

Nowak, G. (1996). Die österreichischen Berufsinformationszentren. Wien: Wissenschaftsverlag.

OECD (2004). Career Guidance: A Handbook for Policy Makers. Paris: OECD.

Oreopoulos, P. and R. Dunn (2013). Information and College Access: Evidence from a Randomized Field Experiment. Scandinavian Journal of Economics 115(1), 3-26.

Papay, J. P., R. J. Murnane, and J. B. Willett (2011). How Performance Information Affects Human-Capital Investment Decisions: The Impact of Test-Score Labels on Educational Outcomes. NBER Working Paper (17120), 1-50.

Perrey, D. (1995). Ergebnisse der repräsentativen Befragung 1994 von Nutzern der BIZMediotheken in den alten und neuen Bundesländern. Informationen für die Beratungs- und Vermittlungsdienste der Bundesanstalt für Arbeit - Nürnberg (4), 333-340.

Rahmenvereinbarung (2004). Rahmenvereinbarung über die Zusammenarbeit von Schule und Berufsberatung zwischen der Kultusministerkonferenz und der Bundesagentur für Arbeit, 15 October 2004, State of Bremen.

Rodríguez-Planas, N. (2012). Longer-Term Impacts of Mentoring, Educational Services, and Learning Incentives: Evidence from a Randomized Trial in the United States. American Economic Journal: Applied Economics 4(4), 121-139.

Schweikert, K. and V. Meissner (1984). Berufswahl und Berufsinformation - Ergebnisse einer empirischen Untersuchung. Beiträge zur Arbeitsmarkt- und Berufsforschung (85). 
Siebert, R. (1979). Das BIZ-Berlin. In Gemeinnützige Gesellschaft Gesamtschule (Ed.), Berufsorientierung und Berufswahlvorbereitung, pp. 80-84. Hamburg.

Stinebrickner, T. R. and R. Stinebrickner (2011). Math or Science? Using Longitudinal Expectations Data to Examine the Process of Choosing a College Major. NBER Working Paper (16869), 1-30.

Vereinbarung (2011). Vereinbarung zwischen der Senatorin für Bildung und Wissenschaft and der Regionaldirektion Niedersachsen-Bremen der Bundesagentur für Arbeit über die Zusammenarbeit von Schule und Berufsberatung, 4 April 2011, p. 4.

Vikström, J., M. Rosholm, and M. Svarer (2011). The Relative Efficiency of Active Labour Market Policies: Evidence from a Social Experiment and Non-Parametric Methods. IZA Discussion Paper (5596), 1-34.

Weitzel, H.-J. (1987). BIZ: Medien- und Kommunikationszentrum des Arbeitsamtes. Landesarbeitsamt NRW.

Weitzel, H.-J. (1988). BIZ: Integrations- und Kooperationsort der Beratungs- und Vermittlungsdienste der BA. arbeit und beruf. Fachzeitschrift für die Aufgaben der Bundesanstalt für Arbeit 39(10), 313-314.

Winkelmann, R. (1996). Employment Prospects and Skill Acquisition of Apprenticeship-Trained Workers in Germany. Industrial and Labor Relations Review 49(4), 658-672.

Wiswall, M. and B. Zafar (2011). Determinants of College Major Choice: Identification Using an Information Experiment. Staff Report. Federal Reserve Bank of New York (500), 1-60.

Zafar, B. (2011). How Do College Students Form Expectations? Journal of Labor Economics 29(2), 301-348. 


\section{Appendix}

Figure A-1: Example of a Content Page from an Information Folder
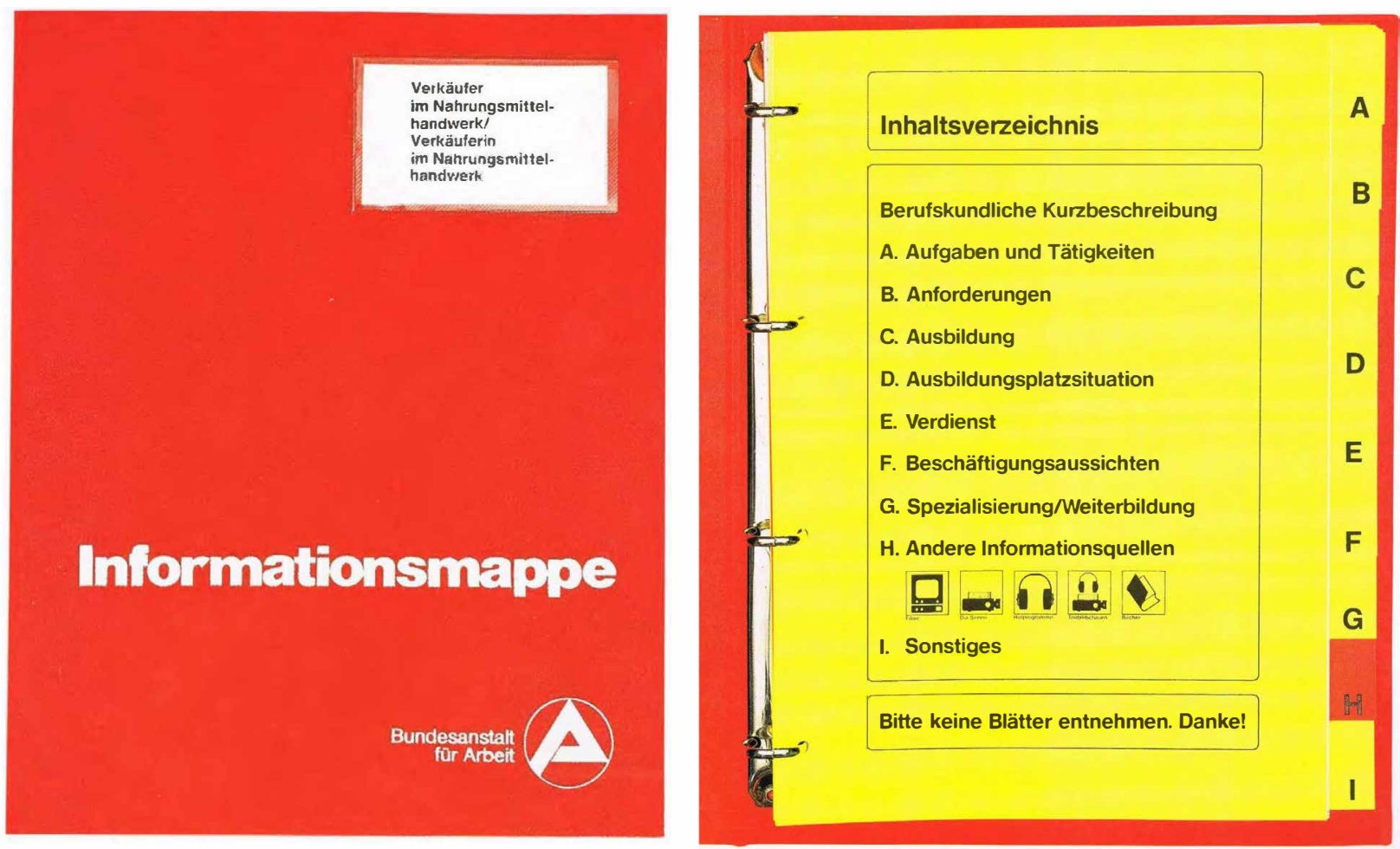

Source: Weitzel (1987), p. 8. Right-hand page translated into English: Content Page. Short description of the occupation. A. Duties and Tasks; B. Requirements; C. Education; D. Availability of Traineeships; E. Income; F. Employment Prospects; G. Specialization and Advanced Training; H. Other Information Media; I.

Miscellaneous. Please do not remove pages. Thank you. 
Figure A-2: Data Sources
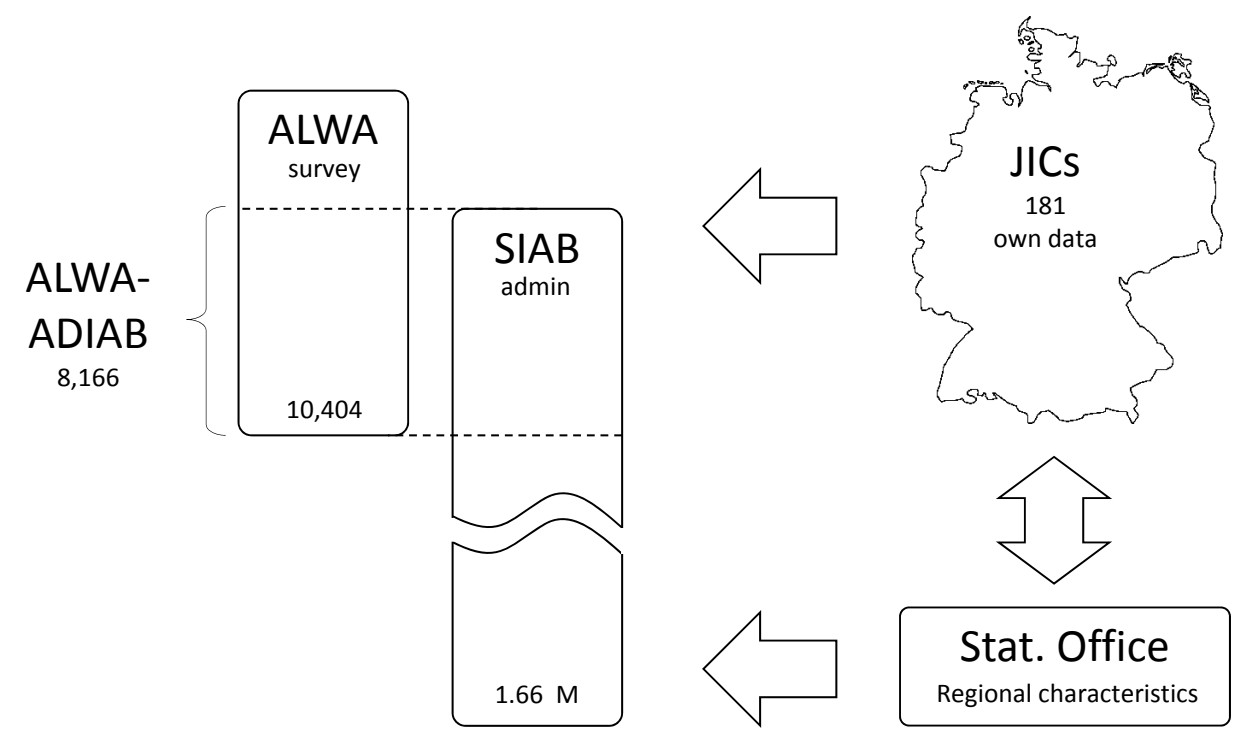

Note: The treatment variable is constructed using the ALWA data and own data about the location and opening time of job information centers. The outcome variables daily wages first job and daily wage at age 35 use entries from SIAB that were matched with the ALWA at the individual level, forming the ALWA-ADIAB subsample of 8,166 observations. All regressions control for the population density of the district of potential treatment in the year 1995. This variable stems from administrative data from the Federal Statistical Office. In the survival analysis regressions, regional characteristics from this source are combined with the JIC data, and with further regional characteristics generated from SIAB. Finally, the SIAB provides the data base for the common trend graphs. 
Table A-1: Description of Variables

\begin{tabular}{|c|c|c|}
\hline Name & Description & Data source \\
\hline \multicolumn{3}{|l|}{ Dependent variables } \\
\hline \multicolumn{3}{|c|}{ Education and Educational Mobility } \\
\hline & Highest general school degree attained is a ... & \\
\hline Low-track degree & low-track school track degree $[1 / 0]$ & ALWA \\
\hline Intermediate-track degree & intermediate-track school track degree (Mittlere Reife) $[1 / 0]$ & ALWA \\
\hline Upper-track degree & upper-track school degree (Abitur) $[1 / 0]$ & ALWA \\
\hline Upward mobility & $\begin{array}{l}\text { Received a school degree from a track higher than the } \\
\text { track attended at time of potential treatment }[1 / 0]\end{array}$ & ALWA \\
\hline University degree & Received a degree from higher education $[1 / 0]$ & ALWA \\
\hline \multicolumn{3}{|c|}{ Labor Market Attachment } \\
\hline & During first five years after finishing formal education... & \\
\hline Incidence part-time & $\ldots \geq$ one month of part-time employment $[1 / 0]$ & ALWA \\
\hline Incidence full-time & $\ldots \geq$ one month of full-time employment $[1 / 0]$ & ALWA \\
\hline Incidence unemployment & $\ldots \geq$ one month of unemployment $[1 / 0]$ & ALWA \\
\hline Duration part-time & ... number of months of part-time employment & ALWA \\
\hline Duration full-time & ... number of months of full-time employment & ALWA \\
\hline Duration unemployment & ... number of months of unemployment & ALWA \\
\hline \multicolumn{3}{|c|}{ Job Search and Job Matching } \\
\hline Search duration & $\begin{array}{l}\text { Number of months between last episode of formal } \\
\text { education and first episode of regular employment }\end{array}$ & ALWA \\
\hline Stayed in district & $\begin{array}{l}\text { Lives in same district at time of survey as two } \\
\text { years before graduating from school }\end{array}$ & ALWA \\
\hline Stayed in state & $\begin{array}{l}\text { Lives in same state at time of survey as two } \\
\text { years before graduating from school }\end{array}$ & ALWA \\
\hline Share invol. job changes & $\begin{array}{l}\text { Share of employment spells that ended involuntarily } \\
\text { during first five years after end of formal education }\end{array}$ & ALWA \\
\hline \multicolumn{3}{|c|}{ Daily Pay (Euros, logarithm) } \\
\hline Pay for first job & $\begin{array}{l}\text { Gross daily pay of first regular employment } \\
\text { after finishing formal education (1995 prices) }\end{array}$ & ALWA-ADIAB \\
\hline Pay at age 35 & Gross daily pay at age 35 (1995 prices) & ALWA-ADIAB \\
\hline Pay for last job & Monthly net pay at time of interview (2007 prices) & ALWA \\
\hline Net income & Monthly total net income at time of interview (2007 prices) & ALWA \\
\hline \multicolumn{3}{|l|}{ Treatment variable } \\
\hline Job information center (JIC) & $\begin{array}{l}\text { JIC existed in district in which individual lived in } \\
\text { two years before graduating from school }[1 / 0]\end{array}$ & $\begin{array}{l}\text { Own data \& } \\
\text { ALWA }\end{array}$ \\
\hline \multicolumn{3}{|l|}{ Other explanatory variables } \\
\hline Migrant background & Citizenship other than German $[1 / 0]$ & ALWA \\
\hline Female & Individual is female $[1 / 0]$ & ALWA \\
\hline FE school track & $\begin{array}{l}\text { Dummies for school track at time of potential treatment } \\
\text { (three groups) }\end{array}$ & ALWA \\
\hline FE mother school degree & Dummies for mother's highest school degree (three groups) & ALWA \\
\hline FE father school degree & Dummies for father's highest school degree (three groups) & ALWA \\
\hline FE population density & $\begin{array}{l}\text { Dummies for population density of the district lived in } \\
\text { at time of potential treatment (ten groups) }\end{array}$ & $\begin{array}{l}\text { Federal Stat. } \\
\text { Office }\end{array}$ \\
\hline
\end{tabular}


Table A-2: Derivation of Potential Treatment Year

(1)

Spell's school track Spell's school degree
$(3)$

Definition of $t$

(a) School degree successfully obtained

$\begin{array}{ccc}\text { low } & \text { low, intermediate, high } & \text { graduation year - 2 } \\ \text { intermediate } & \text { intermediate } & \text { graduation year - 2 } \\ \text { intermediate } & \text { low } & \text { graduation year - 1 } \\ \text { high } & \text { high } & \text { graduation year - 3 } \\ \text { high } & \text { low, intermediate } & \text { graduation year - 1 }\end{array}$

(b) School dropouts or school track changers

\begin{tabular}{|c|c|c|}
\hline low & 一 & year at age 13 \\
\hline intermediate & - & year at age 14 \\
\hline high & - & year at age 16 \\
\hline
\end{tabular}

(c) No potential treatment year derivable

school outside Germany, unknown school type, unknown degree achieved, ongoing school spells, school not main activity, evening school

Source: Own definition based on framework agreements between the Federal Employment Agency and local school authorities. $t=$ potential treatment year, low-track school=Hauptschule, intermediate-track school=Realschule, upper-track school= Gymnasium. 


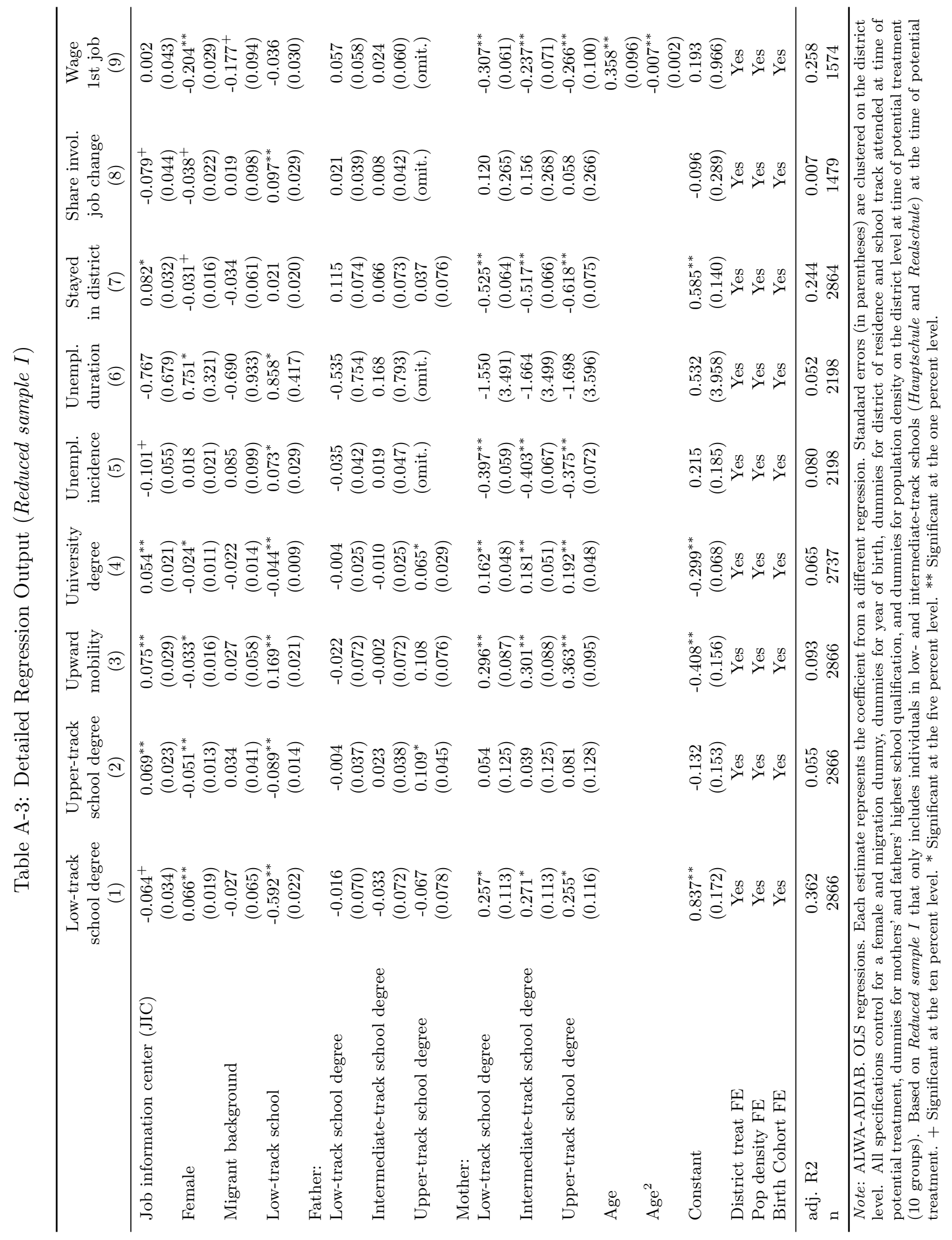

